\title{
Telomeres, Aging and Exercise: Guilty by Association?
}

\author{
Warrick Chilton ${ }^{1, *}$, Brendan $\mathrm{O}^{\prime}$ Brien $^{1}$ and Fadi Charchar $1,2,3, *$ \\ 1 Faculty of Health Sciences and Faculty of Science and Technology, Federation University Australia, \\ Ballarat, VIC 3350, Australia; b.obrien@federation.edu.au \\ 2 Department of Physiology, University of Melbourne, Melbourne, VIC 3010, Australia \\ 3 Department of Cardiovascular Sciences, University of Leicester, Leicester LE1 7RH, UK \\ * Correspondence: w.chilton@federation.edu.au (W.C.); f.charchar@federation.edu.au (F.C.); \\ Tel.: +61-3-5327-6254 (W.C.); +61-3-5327-6098 (F.C.)
}

Received: 7 September 2017; Accepted: 25 November 2017; Published: 29 November 2017

\begin{abstract}
Telomeres are repetitive tandem DNA sequences that cap chromosomal ends protecting genomic DNA from enzymatic degradation. Telomeres progressively shorten with cellular replication and are therefore assumed to correlate with biological and chronological age. An expanding body of evidence suggests (i) a predictable inverse association between telomere length, aging and age-related diseases and (ii) a positive association between physical activity and telomere length. Both hypotheses have garnered tremendous research attention and broad consensus; however, the evidence for each proposition is inconsistent and equivocal at best. Telomere length does not meet the basic criteria for an aging biomarker and at least $50 \%$ of key studies fail to find associations with physical activity. In this review, we address the evidence in support and refutation of the putative associations between telomere length, aging and physical activity. We finish with a brief review of plausible mechanisms and potential future research directions.
\end{abstract}

Keywords: telomeres; aging; physical activity; biomarker; association

\section{Introduction}

The global population of persons aged 80 years or older will triple by 2050 [1], leading inexorably to a public health imperative. Current increases in life expectancy exceed concomitant increases in disease free years, creating a compression of chronic disease burden in old age [2]. Physiological aging is characterized by cumulative deleterious changes to biological function [3] and is the strongest non-modifiable predictor of most chronic diseases. Despite this, significant variability exists in the health impact of aging [4].

The associations between mortality and traditional biomarkers such as blood pressure, cholesterol and body mass index (BMI) weaken with age [5]. The search for a definitive aging biomarker is encumbered by the heterogeneity of cellular aging. Post-mitotic cells are not subjected to the replicative stresses experienced by mitotic cells; therefore, some tissues exhibit greater biological aging than others. The highly variable human lifespan highlights that the mere passage of chronological time is not an effective, isolated measure of aging. Biological aging refers to processes that proceed independently of chronological aging that reduce organismal viability and increase vulnerability. Telomeres are regarded by many as the heir apparent of aging biomarkers, recording both chronological and biological age [6,7].

\section{Telomere Biology—A Primer}

Telomeres are specialized DNA structures that bookend nuclear DNA protecting it from degradation [8]. Mitotic division imposes a progressive loss of telomeric base pairs (bps) due to 
the inability of DNA polymerases to fully replicate the lagging C-strand $[9,10]$. This cumulative loss simultaneously chronicles replicative history and imposes a finite replicative limit. Critical shortening of telomeres causes eventual disruption of the protective protein shelterin complex [11]. Cells requiring high replicative capacity express telomerase, a specialized ribonucleoprotein complex that synthesizes telomeric repeats [12]. Human telomerase consists minimally of two core components; a reverse transcriptase catalytic subunit (hTERT) and an antisense RNA template (hTERC) [12,13]. Telomeres are sensitive to a host of stimuli including oxidative stress [14], chronic inflammation [15], BMI [16], smoking [17], alcohol intake [18], perceived stress [19] and physical activity (PA) [20]. A growing body of evidence also indicates that telomeres are responsive to habitual PA [20,21].

Despite the telomere's popular designation as a mitotic clock, the relationship between telomere length and aging is inconsistent and does not meet the requisite biomarker criteria [22]. Closer examination of the association with PA also reveals inconsistencies and methodological confounders. The clinical and public interest in the PA-telomere association is predicated upon several tacit assumptions: (i) mean telomere length is causally associated with biological aging and age-related pathologies and (ii) PA can lengthen mean telomere length and that in doing so; (iii) PA will reduce biological aging and disease burden. This review summarizes the current evidence for and against telomeres as aging biomarkers of aging and potential mediators of exercise-induced health gains.

\section{Cellular Senescence}

Cellular senescence is the progressive and irreversible loss of replicative capacity in somatic cells [23]. Cellular senescence sits astride several paradoxical and seemingly incongruent binary functions; namely tissue regeneration [24] and tissue dysfunction [25], embryonic development [26] and organismal aging [27] and tumor promotion [28] and suppression [29]. Senescence is triggered when the telomeric terminal restriction fragment (TRF) reaches a mean length of $4-7 \mathrm{~kb}$ [30]. At this critical threshold, the protective shelterin complex is disrupted exposing an uncapped double-stranded chromosome end. This in turn triggers the ataxia telangiectasia mutated (ATM)-p53-p21 axis and subsequent DNA damage response (DDR) [31], preventing progression into the S-phase of the cell cycle [32-34].

Replicative senescence refers to proliferative exhaustive driven by telomere loss whilst stress-induced senescence can be precipitated by oxidative or genotoxic stress, regardless of telomere length [35]. Replicative senescence is causally implicated in aging and age-related diseases such as cardiovascular disease (CVD) [36], diabetes [37,38], osteoarthritis [39], glaucoma [40] and cataracts [41]. In addition to lost proliferative capacity, cellular senescence causes significant changes in gene expression, epigenetic factors and cell morphology [42]. Senescent cells also acquire a characteristic secretome known as the Senescence-Associated Secretory Phenotype (SASP) [43]. This largely pro-inflammatory phenotype can initiate senescence in young cells contributing to tissue dysfunction [25], progression of atherosclerosis [36], cancer [44] and diabetes [37,38].

Replicative exhaustion within the immune system is called immunosenescence; a cluster of age-related changes resulting in decreased replicative capacity $[45,46]$, shortened telomeres [47], increased cytokine production [48,49] and increased susceptibility to infectious diseases [50]. Given the diverse physiological ramifications, senescence may be the causal nexus linking the indirect, microscopic causes of aging with the direct, macroscopic effects of aging [27].

\section{Telomeres and Aging}

A clear inverse association exists between chronological age and telomere length. Support of the causal association between telomeres and aging comes from accelerated aging conditions such as Dyskeratosis Congenita, Werner's Syndrome and Hutchinson-Gilford Syndrome. Such progeroid syndromes are characterized by a sequela of age-associated pathologies precipitated by accelerated telomere attrition [51-55]. 
The American Federation of Aging Research stipulate that any candidate aging biomarker must satisfy the following criteria [56,57]:

1. It must predict the rate of aging and therefore be a better predictor of lifespan than chronological age

2. It must reflect and monitor the physiological processes underlying aging

3. It must be a repeatable, unobtrusive and harmless measure

4. It must be testable in animal models

\subsection{Criterion 1-Must Predict the Rate of Aging Better than Chronological Age}

Human telomere length varies by 5000 to 15,000 bps at birth [58], a measure that exceeds total average leukocyte telomere length (LTL) shortening throughout adult life [59]. Genome-wide association studies have identified a host of potential candidate loci associated with LTL variation [60-65]. Estimates of telomeric bp loss vary between 30-200 bps per division $[66,67]$. Although variable in magnitude, age-related decreases in LTL are consistently observed [68]. Three recent studies estimated the annual telomere shortening rate at 17.4 [69], 15.6 [70] and 48-67 bps per chronological year [71]. Paternal age at conception of the offspring is associated with longer offspring LTL [72-74], yet infant LTL is positively associated with adult telomere attrition rate [75,76]. However, the annual adult attrition rate contributes less to population LTL variation than LTL variation at birth [77] and attrition rate during the first two decades of life [78,79]. Unlike chronological age, telomere shortening is not linear; the majority of shortening occurs during the rapid somatic expansion from birth to puberty $[80,81]$. Thereafter, adults with either longer or shorter than average LTL tend to maintain that classification into old age $[82,83]$. Telomere shortening can be heterogeneous within a given cell as longer telomeres shorten faster than shorter ones [84-86].

Paradoxically, telomere lengthening has been observed in several longitudinal studies $[75,76,87-95]$. When assessed over a $2-6$ year period, most individuals shorten or maintain telomere length; however, $15-44 \%$ demonstrate an increase in mean LTL $[87,89,96]$. The assessment time course appears important as less lengthening is observed when assessed over a 10 year period [97]. Post-intervention increases in telomere length may be due to actual telomerase-mediated addition of telomeric DNA or an apparent lengthening due to redistribution of immune cell subsets [98]; a caveat seldom declared in telomeric research.

More people are living into old age; however, these people eventually die within a very narrow time span as the finite biological limit of human lifespan is reached [99]. If telomere length reliably scaled with lifespan, individuals with shorter telomeres would theoretically die off before reaching the limits of human lifespan. This would result in an age-associated decrease in telomere length variance known as survivor bias; a phenomenon that has been demonstrated $[100,101]$ and refuted in the data [102]. Most individuals are not living long enough to reach the critically shortened telomere threshold referred to as the telomeric brink. It is believed that further increases in longevity will be limited by telomere length [103]. Given an average starting LTL of 10-15 kilobase pairs, even a yearly loss of approximately $50 \mathrm{bps}$ should still sustain lymphocyte function well beyond 100 years of age. This appears to support the theory that the length of the shortest telomere, as opposed to the average telomere length, triggers cell cycle arrest, genomic instability and senescence [85]. Overall, LTL appears to add predictive power to health measures but is less effective than chronological age [104]. This may be due to high variability in LTL at birth and throughout the lifespan.

\subsection{Criterion 2-The Capacity to Reflect Physiological Processes}

Telomeres possess clear biological plausibility as a candidate aging biomarker, reflecting oxidative stress, inflammation, replicative history and cellular senescence. Despite that, associations with age-sensitive functional measures are inconsistent. Several studies have failed to find associations between LTL and lung function [105], grip strength [18], blood pressure [106] and several measures of 
cognitive function $[18,101]$. However, a more recent investigation identified associations with lung function, grip strength, pulse pressure, reaction time, general mental ability and general health [104]. The Newcastle 85+ study assessed associations between a panel of 74 candidate biomarkers and four health-status measures in a cohort of 852 individuals aged 85 years. Leukocyte telomere length did not fulfil the criterion of significant association with at least two of the health-status measures [107].

Boonekamp et al. propose that organisms consist of redundancy elements that gradually fail and replace each other as they buffer and accumulate damage. Death occurs when the last of the elements are exhausted. Boonekamp et al. further propose that LTL is better viewed as a biomarker of somatic redundancy than biological aging [108]. The somatic redundancy model fits with two established telomere observations: (i) that longer telomeres, possessing more redundancy units, shorten faster than short telomeres [84] and (ii) telomere shortening only becomes detrimental when a critical threshold is passed [109]. The current evidence indicates that LTL likely reflects pre-pubertal somatic growth and post-pubertal cellular senescence and oxidative stress [58].

\subsection{Criterion 3-A Harmless Repeatable Measure}

Most studies measure mean telomere length in circulating leukocytes as physiological proxy for the target tissue. Conclusions from these studies are predicated upon a supposed correlation between LTL and target tissue. One study correlated LTL with vascular tissue telomere length [110] and there is evidence of intra-individual correlation in telomere length between different tissues [111,112]. A more recent study found correlations with only two (intercostal skeletal muscle and liver) out of twelve human tissues assessed [113]. Experimental data suggests that differences in telomere length between tissues are due to tissue-specific attrition rates [114]; however, these rates appears to regress towards a mean value from adulthood to old age [79].

Mean LTL represents the average telomere length across a heterogeneous cell population. A recent study rank-ordered telomeres as longest in B cells, then CD4+ and CD8+CD28+ T cells (similar lengths) and shortest in senescent CD8+CD28- $T$ cells [115]. Telomerase expression is also heterogeneous within the immune system; being highest in B cells, followed by CD4+ T cells, CD8+CD28+ T cells and lowest in CD8+CD28- T cells [115]. Exercise is known to transiently modulate the relative proportions of leukocyte subsets in an intensity-dependent fashion [116]. Therefore, the cellular composition at any given time point will determine the mean LTL and telomerase activity [115].

Considerable variance exists within and between telomere measurement techniques. At present, several different protocols can be used to measure telomere length [117]. These range from the original gold standard Southern blot analysis of terminal restriction fragment (TRF), quantitative polymerase chain reaction-based techniques (qPCR), through to single telomere length analysis (STELA), flow and quantitative fluorescence in situ hybridization (flow FISH and Q-FISH respectively). Each has its own strengths, limitations and coefficient of variation $(\mathrm{CV})$, making comparisons between studies potentially inaccurate. Data from qPCR and Southern blot are weakly correlated $(r=0.52)$ [118]. Comparison between qPCR and flow FISH obtained a similarly weak correlation coefficient $(r=0.47)$ [119]. Next generation sequencing (NGS) technology has given rise to new methods of telomere length measurement. The two key proposed methods both count short reads that contain telomeric repeats [120] and are appropriate for assessment of mean telomere length in genome [121]. However, there is considerable variation between NGS methods and qPCR-based measurements at present [122]. Differences in DNA extraction protocol also significantly influence telomere length [123]. Similarly, telomerase can also be assessed using multiple protocols and variants thereof, either directly measuring telomerase products or signals from telomerase-mediated DNA [124].

The likelihood of measurement error in telomere research is high. The inter-individual variation in LTL can be 5000 to 15,000 bps [58] whilst the yearly shortening rates can vary between 30-100 bps [125]. The majority of telomere research utilizes qPCR which has a CV of $6.45 \%$ compared to TRF which has a $\mathrm{CV}$ of $1.74 \%$ [117]. Such variation is likely to render many associations non-significant or questionable at the very least. 


\subsection{Criterion 4-Testable in Animal Models}

Animal models have significantly furthered the understanding of telomere homeostasis and disease; however, some inherent limitations affect direct inter-species comparisons. The life expectancy of a mouse is more than 40 times shorter than that of a human yet mouse telomeres are 5 to 10 times longer [126]. The telomerase enzyme is functionally active in the majority but not all, murine tissues [127]; as distinct from humans that lack detectable telomerase levels in many somatic cells [128]. The telomerase-negative $\mathrm{mTR}^{-/-}$mouse was initially developed to examine the role of telomerase in normal and neoplastic growth [129]. It has since made valuable contributions to the understanding of telomere regulation. However, in addition to exhibiting telomere dysfunction and increased end-to-end fusions $[129,130]$, late generation $\mathrm{mTR}^{-/}$- mice can also exhibit a host of other pathological phenotypes [130-139]. Knock-in of telomerase eliminates many of the degenerative phenotypes observed in late generation $\mathrm{mTR}^{-/-}$mice [140]. The comparatively sterile laboratory conditions mice are subjected to remove several negative telomere instigators such as variable diets, pollution, ultraviolet light and inflammation [141].

Whilst rodents are the most widely used animal models, zebrafish have also been used extensively in telomere/telomerase research. Their short life, relatively short generation time and an unlimited capacity to regenerate their fins in 7-10 days makes them a convenient model [142,143]. Expression levels of zebrafish TERT mRNA closely correlate with telomerase activity and in accordance with most marine species, they appear to maintain telomerase expression in somatic tissues [144]. A telomerase-mutant zebrafish strain has been widely used to study aging phenotypes; however, it demonstrates aging phenotypes that are far more pronounced than wild-type animals [145]. Telomere/telomerase has also been investigated in avian species [146], primate species [147], plants [148,149], nematodes [150,151] and Drosophila [152]. Each animal model has made contributions to the understanding of telomere homeostasis; however, most have physiological discontinuities that challenge their representativeness of normal human aging.

\section{Telomeres and Age-Related Diseases}

Variable associations exist between accelerated telomere shortening and age-related diseases such as CVD [96,153,154], cancer [155], stroke [156] diabetes [157-159], dementia [160-162], chronic obstructive pulmonary disease [163] and skin disorders [164]. Shorter LTL was initially associated with coronary artery disease (CAD) in 2001 [165]; with similar CVD associations to follow [106,153,166-173]. Short LTL but not attrition rate, was recently associated with carotid atherosclerosis progression [174]. Moreover, short telomeres were more strongly associated with early-onset than late-onset atherosclerosis. A host of CVD risk factors have also been observationally associated with shortened LTL including smoking [17], diabetes [158], hypercholesterolemia [175], hypertension [176], obesity [177], physical inactivity [20], alcohol consumption [178] and psychological issues [179]. Several other studies have not found associations with blood lipid status [15], hypertension [15,153], smoking [101,180] and BMI [101,180]. A more recent study found no associations between LTL and coronary risk factors including cholesterol, triglyceride, HDL-cholesterol, LDL-cholesterol, smoking, personal or family history of CVD [181].

Three key studies have since failed to find any association between LTL and early atherosclerosis [173,182,183]. Additionally, a recent study associated long, as opposed to short LTL with a nearly three-fold higher risk of developing myocardial infarction [184]. Support for a causal link continues to come from genetic and observational prospective studies using Mendelian randomization to reduce the likelihood of reverse causation. A cluster of seven alleles associated with shortened LTL are themselves associated with a 21\% increased CAD risk per standard deviation in LTL [185-187]. Despite an abundance of conflicting evidence, the broader scientific consensus is that shortened LTL represents an increased risk of CVD and likely reflects accelerated leukocyte turnover due to oxidative stress and inflammation. 
Accumulating evidence indicates an independent pro-telomeric effect of statin treatment [188]. Aspirin decreases oxidative stress and forestalls endothelial cell senescence [189] yet inhibits telomerase activation in polymorphonuclear neutrophils from carotid plaques [190]. Angiotensin-converting enzyme (ACE) inhibitors also demonstrate a pro-telomeric effect via upregulation of TERT mRNA in endothelial cells [191]. Androgen treatment also significantly increased LTL in a cohort with telomere-shortening diseases [192].

The relationship between LTL and cancer is complex and at times paradoxical. A detailed treatment of the role of telomeres in malignant transformation is beyond the scope of this review. What follows is a brief overview of current evidence. Telomere shortening and uncapping (loss of shelterin integrity) are believed to play an anticancer role [193]. Long LTL is associated with increased risk of several cancer types [194-203]. However, in some instances shortened telomeres can potentiate cancer by fusing with other uncapped telomeres, thereby creating genome destabilizing fusion-bridge-breakage cycles [193]. Telomerase activity is a critical component in malignant transformation with $85-90 \%$ of all malignant tumors being telomerase positive $[128,204]$. It is estimated that $\sim 15 \%$ of human cancers maintain telomere length through one or more mechanisms referred to as Alternative Lengthening of Telomeres (ALT) [205]. A cluster of seven alleles associated with LTL homeostasis, TERC, TERT, oligonucleotide/oligosaccharide-binding fold containing one gene (OBFC1), zinc finger protein 208 (ZNF208), regulator of telomere elongation helicase 1 (RTEL1), acylphosphatase 2 (ACYP2) and nuclear assembly factor 1 ribonucleoprotein (NAF1) are simultaneously associated with CAD [185] and cancer [195,198]. If the alleles result in comparatively long telomeres, the cancer risk is elevated and the CAD risk is reduced; the reverse is also true. It has been proposed that the cancer protection conferred by short telomeres represents an evolutionary trade-off resulting in decreased proliferative and regenerative capacity [206]. Non-linear U-shaped relationships have been observed between telomere length and several cancer risk profiles [207]. This may in part be explained by the destabilizing and potentially oncogenic effects of shortened telomeres [208] and the increased replicative capacity and potential accumulation of abnormalities associated with longer telomere length [209].

One proposed explanation for the discrepant associations is that telomere uncapping has an anti-cancer effect in the young but a potentially pro-cancer effect in the elderly [210]. Hypothetically, the more robust telomere dysfunction-based mechanism of the young would prevent tumorigenesis whilst the shortened, uncapped and depleted telomeres of the elderly may allow bypass of aberrant cells [210].

\section{Telomeres, Longevity and Mortality}

The association with overall longevity is similarly inconsistent. Whilst several studies support an association with longevity [211-214], just as many refute it $[101,180,215,216]$. However, the observation that LTL is longer in women may be linked to the greater longevity observed in women [217]. Additionally, in twin studies, the individual with longer LTL exhibits enhanced longevity compared to the other twin [218].

A range of studies have identified age-adjusted inverse associations between mean LTL and all-cause mortality $[69,88,160,162,211,212,219-227]$. However, other studies were unable to replicate the association in similar cohorts $[18,91,96,101,153,180,215,216,228-230]$. Analysis of cohorts from Costa Rica, Taiwan and United States of America found that after adjustment for gender and age, LTL ranked between 15th and 17th out of 20 established predictors and biomarkers of all-cause mortality [231]. A cohort of 4576 healthy individuals had LTL measured twice within a 10-year interval and were then monitored for morbidity and mortality for another 10 years. Change in LTL and risk of all-cause mortality were not significantly associated [95]. Despite abundant associations between telomere length and age-associated mortality, the association diminishes with age [108]; failing to predict mortality in cohorts of the very old $[101,180]$. Paradoxically, telomere length in early childhood most accurately predicts life expectancy $[108,232]$. 


\section{Physical Activity and Telomere Length}

The widely touted relationship between PA and LTL is replete with inconsistencies. Support for a positive association has come from a range of observational/cross-sectional studies $[20,179,223,233-248]$. A summary of human studies that significantly associated PA with telomere length is contained in Table 1. Telomere length has been assessed in skeletal muscle cells and white blood cells (WBCs) in response to aerobic training, resistance training and self-reported PA. The observed associations appear hormetic, with low and excessive levels of activity associated with shorter telomeres [241,244] and moderate levels more commonly associated with longer LTL [223].

A 2016 study of 6474 males and females positively associated running with LTL yet found no associations with other PA domains including aerobics, basketball, bicycling, dancing, running, stair climbing, swimming, walking and weight-lifting [249]. The authors speculate that the sustained weight-bearing status of running may preferentially activate signaling pathways, citing other studies that demonstrated associations in ultra-endurance runners [234]. One can only speculate that insufficient statistical power explains the lack of association found in other studies employing running as the independent variable $[250,251]$. Self-reported PA was positively associated with LTL in a cohort of 5823 men and women from the National Health and Nutrition Examination Survey (NHANES) [70]. Objectively measured maximal cardiorespiratory fitness $\left(\mathrm{VO}_{2 \max }\right)$ has also been positively associated with LTL in a cohort of obese women [252] and older exercise-trained participants [239].

The positive associations have been refuted by several observational and interventional studies $[15,89,97,250-266]$. A summary of human studies that found no significant association between PA and telomere length is contained in Table 2. A rigorous 2015 systematic review and meta-analysis concluded that insufficient quality evidence exists to conclusively associate PA with LTL [267]. Approximately $54 \%$ of studies reviewed found no relationship between PA and LTL; $41 \%$ found a positive association and $5 \%$ identified a curvilinear relationship [267]. Most of the positive associations were weak to moderate with only two studies reporting strong associations $[223,234]$. The analysis cited methodological issues such as weak correlations, assessment of varied tissue types, arbitrary cuff-off points, inadequate blinding of researchers, selective inclusion of other potentially confounding lifestyle factors and discrepant measurement techniques as possible confounders [267]. Discrepant modes of PA and the wide-spread use of self-reported PA with its inherent biases may also explain the lack of association in several of the studies. A similar review conducted in 2013 assessed the effect of exercise in animals and humans and identified three general association types: positive association, inverted "U" response and no association [21].

Whilst some studies identify beneficial chronic effects of exercise on telomere length, acute telomere shortening has also been observed within the same cohort [268]. A study of 2006 Chinese participants found no significant difference in LTL across quartiles of PA [266]. Crucially, the author cited possible decreased role of PA in the seventh decade given potential selection bias of recruiting healthy elderly participants. A common criticism of studies failing to find associations with PA is the lack of statistical power; however, a range of studies with sample sizes ranging from 1942-5862 participants have failed to find an association between PA and LTL [15,95,253,264-266]. In a cohort of 4576 Danish men and women, PA was not associated with LTL change over 10 years [95]. A study by Sun et al. (2012) did not demonstrate an association between PA and LTL in a cohort of 5862 middle-aged women [264]; however, the addition of five low-risk factors (smoking status, PA, adiposity, alcohol use and diet) to the analysis established a significant association. 
Table 1. A summary of studies showing positive associations between physical activity and telomere length.

\begin{tabular}{|c|c|c|c|c|}
\hline Ref. & Subjects $(n)$ & Tissue & Measurement & Key Findings \\
\hline [19] & $\begin{array}{l}63 \text { healthy post-menopausal women; sedentary group, } \\
\text { active group }\end{array}$ & Leukocytes & $\mathrm{T} / \mathrm{S} \mathrm{qPCR}$ & $\begin{array}{l}\text { Sedentary: one unit increase in the Perceived Stress Scale }=15 \text {-fold increase in odds of having } \\
\text { short telomeres }(p<0.05) \text {. } \\
\text { Active: Perceived stress unrelated to telomere length }(p=0.45) \text {. }\end{array}$ \\
\hline$[20]$ & White twins 2401: 2152 females, 249 males & Leukocytes & Southern blot TRF & $\begin{array}{l}\text { Leisure time PA positively associated with LTL }(p<0.001) \text {. } \\
\text { LTLs of the most active subjects were } 200 \text { nucleotides longer than least active }(p=0.006) \text {. }\end{array}$ \\
\hline [70] & 5823 adult participants; males $(n=2766)$, females $(n=3057)$ & Leukocytes & $\mathrm{T} / \mathrm{S} \mathrm{qPCR}$ & $\begin{array}{l}\text { Relative PA }(p<0.0002) \text { and absolute PA }(p=0.0052) \text { associated with longer LTL after } \\
\text { adjustment for demographic variables. } \\
\text { Prevalence of short telomeres associated with relative PA }(p<0.0001) \text {. }\end{array}$ \\
\hline [179] & $\begin{array}{l}1552 \text { Caucasian female twins: } 749 \text { dizygotic twins, } \\
27 \text { monozygotic twins. Distributed into six socioeconomic } \\
\text { status (SES) groups }\end{array}$ & Leukocytes & Southern blot TRF & $\begin{array}{l}\text { PA positively associated with TRFL }(p<0.005) \text {. } \\
\text { Overall decreasing trend in TRFL with lower SES }(p<0.024) \text {. } \\
\text { Significant difference in TRFL between non-manual and manual workers }(p<0.01) \text {. }\end{array}$ \\
\hline [223] & $\begin{array}{l}44 \text { healthy, post-menopausal women, divided into habitual } \\
\text { exercise and sedentary groups }\end{array}$ & Leukocytes & $\mathrm{T} / \mathrm{S} \mathrm{qPCR}$ & LTL significantly higher in habitual exercise group compared to sedentary group $(p<0.01)$. \\
\hline [233] & $\begin{array}{l}274 \text { pairs same sex twins (153 dizygotic pairs, } \\
121 \text { monozygotic pairs) }\end{array}$ & Leukocytes & Southern blot TRF & $\begin{array}{l}\text { LTL is positively associated with self-reported physical ability in all pairs combined }(p=0.006) \text {. } \\
\text { Positive association between PA and LTL in all pairs }(p=0.034) .\end{array}$ \\
\hline [234] & $\begin{array}{l}67 \text { male ultra-marathon runners, } 63 \text { age and sex-matched } \\
\text { controls }\end{array}$ & Leukocytes & $\mathrm{T} / \mathrm{S} \mathrm{qPCR}$ & LTL $11 \%$ longer in ultra-marathon runners compared to controls $(p<0.001)$. \\
\hline [235] & Nurse's health study -7813 females & Leukocytes & $\mathrm{T} / \mathrm{S} \mathrm{qPCR}$ & $\begin{array}{l}\text { Moderately or highly active women had } 0.07 \text { SD increase in LTL compared to least active } \\
(p=0.02) \text {. Greater moderate or vigorous activity associated with longer LTL }(p=0.02) \text {. }\end{array}$ \\
\hline [236] & 392 post-menopausal women with Stage I-III breast cancer & PBMCs & Southern blot TRF & No PA significantly associated with shorter LTL $(p=0.03)$. \\
\hline [237] & 895 participants: 476 females, 419 males & Leukocytes & $\mathrm{T} / \mathrm{S} \mathrm{qPCR}$ & Low frequency PA an independent predictor of short LTL $(p<0.001)$. \\
\hline [238] & $\begin{array}{l}944 \text { participants with stable CHD, distributed into } \\
\text { three exercise capacity groups: low }(n=299) \text {, moderate: } \\
n=334 \text {, high: } n=381\end{array}$ & Leukocytes & $\mathrm{T} / \mathrm{S} \mathrm{qPCR}$ & $\begin{array}{l}\text { LTL significantly longer in subjects with high exercise capacity compared to low }(p<0.001) \text {. } \\
\text { Association remained after adjustment for CVD severity and physical inactivity }(p=0.005)\end{array}$ \\
\hline [239] & $\begin{array}{l}57 \text { participants stratified into four groups: young sedentary } \\
(n=15) \text {, young exercising }(n=10) \text {, older sedentary }(n=15) \text {, } \\
\text { older exercising }(n=17)\end{array}$ & Leukocytes & Southern blot TRF & $\begin{array}{l}\text { LTL of older exercising subjects significantly longer than age-matched sedentary controls } \\
(p<0.001) \text {. LTL of older exercisers not significantly different from young exercisers }(p=0.12) \text {. } \\
\text { LTL positively associated with } \mathrm{VO}_{2 \max }(p<0.01) \text {. }\end{array}$ \\
\hline [240] & $\begin{array}{l}1764 \text { adults: } 51 \% \text { males, } 49 \% \text { females, } 73 \% \text { non-Hispanic } \\
\text { whites; distributed into cardiorespiratory fitness tertiles }\end{array}$ & Leukocytes & $\mathrm{T} / \mathrm{S} \mathrm{qPCR}$ & LTL longer in upper tertile $(p=0.04)$ and middle tertile $(p=0.02)$ compared to lowest tertile. \\
\hline [241] & $\begin{array}{l}69 \text { healthy participants: } 34 \text { males, } 35 \text { females; distributed } \\
\text { into four exercise energy expenditure quartiles }\end{array}$ & PBMCs & $\mathrm{T} / \mathrm{S} \mathrm{qPCR}$ & $\begin{array}{l}\text { Significantly longer telomeres in second exercise energy expenditure quartile compared to first } \\
(p=0.001) \text { and fourth }(p=0.04) \text { quartiles. }\end{array}$ \\
\hline [242] & $\begin{array}{l}20 \text { male participants: } 5 \text { young athletes, } 5 \text { young } \\
\text { non-athletes, } 5 \text { older athletes, } 5 \text { older non-athletes }\end{array}$ & Skeletal muscle & $\mathrm{T} / \mathrm{S} \mathrm{qPCR}$ & $\begin{array}{l}\text { Longer telomeres in older athletes compared to older non-athletes }(p=0.04) \text {. Young athletes not } \\
\text { different to young non-athletes }(p=0.12) \text {. } \\
\text { Strong correlation between } \mathrm{VO}_{2 \max } \text { and } \mathrm{T} / \mathrm{S} \text { ratio in athletes }(p=0.02) \text {. }\end{array}$ \\
\hline [243] & 239 post-menopausal women & Leukocytes & $\mathrm{T} / \mathrm{S} \mathrm{qPCR}$ & $\begin{array}{l}\text { One SD below mean PA levels, major life stressors were associated with LTL shortening } \\
(p=0.008) \text {. One SD above mean PA level, major life stressors were not associated with LTL } \\
\text { shortening }(p=0.48) .\end{array}$ \\
\hline
\end{tabular}


Table 1. Cont.

\begin{tabular}{|c|c|c|c|c|}
\hline Ref. & Subjects $(n)$ & Tissue & Measurement & Key Findings \\
\hline [244] & $\begin{array}{l}782 \text { males: three PA groups low }(n=148) \text {, moderate } \\
(n=398) \text {, high }(n=236)\end{array}$ & Leukocytes & Southern blot TRF & $\begin{array}{l}\text { Inverted " } \mathrm{U} \text { " response. Moderate PA positively associated with longest LTL ( } p=0.03) \text {. } \\
\text { LTL the same in low and high PA groups. Moderate PA group had lowest proportion of short } \\
\text { LTL }(p=0.02) \text {. }\end{array}$ \\
\hline [245] & $\begin{array}{l}46 \text { participants distributed into three PA groups: } \\
\text { never trained }(n=15) \text {, moderately trained }(n=16), \\
\text { intensively trained }(n=15)\end{array}$ & PBMCs & Flow-FISH & $\begin{array}{l}\text { T cell TL longer in moderately trained and intensively trained compared to never trained } \\
(p<0.05) \text {. } \\
\text { Significantly longer telomeres in CD } 8+\text { T cells in IT group }(p<0.05) \text {. }\end{array}$ \\
\hline [246] & $\begin{array}{l}36 \text { healthy participants distributed into three groups: } \\
\text { young }(n=12) \text {, old mobile }(n=12) \text {, old immobile }(n=12)\end{array}$ & Skeletal muscle & $\mathrm{T} / \mathrm{S} \mathrm{qPCR}$ & $\begin{array}{l}\text { Mean TL from leg muscle of the old immobile group was significantly shorter than old mobile } \\
\text { group }(p<0.05) \text {, young group }(p<0.05) \text {, arm muscle }(p<0.05) \text {. }\end{array}$ \\
\hline [247] & $\begin{array}{l}\text { Young sedentary controls }(n=26) \text {, young athletes }(n=32) \text {, } \\
\text { middle-aged sedentary } \\
(n=21) \text {, middle-aged athletes }(n=25)\end{array}$ & Leukocytes & $\begin{array}{l}\text { FlowFISH and } \\
\text { T/S qPCR }\end{array}$ & $\begin{array}{l}\text { Older sedentary controls had shorter mononuclear cell telomeres than all other groups } \\
(p<0.001) \text {. Age-dependent telomere loss attenuated in lymphocytes }(p<0.001) \text { and } \\
\text { granulocytes }(p<0.001) \text { of older athletes. }\end{array}$ \\
\hline [248] & $\begin{array}{l}667 \text { healthy adolescents: } 169 \text { white males, } 179 \text { white females, } \\
155 \text { black males, } 164 \text { black females }\end{array}$ & Leukocytes & $\mathrm{T} / \mathrm{S} \mathrm{qPCR}$ & Vigorous PA positively associated with telomere length $(p=0.009)$ \\
\hline [249] & 6474 participants: $49.6 \%$ males, $50.4 \%$ females & Leukocytes & $\mathrm{T} / \mathrm{S} \mathrm{qPCR}$ & LTL positively associated with running $(p=0.03)$ \\
\hline [268] & 20 endurance athletes, 42 age- and gender-matched controls & Buccal cells & $\mathrm{T} / \mathrm{S} \mathrm{qPCR}$ & $\begin{array}{l}\text { Baseline TL better preserved in endurance athletes }(p=0.003) \text {. } \\
\text { Intermediate TL reduced in endurance athletes compared to baseline }(p=0.002) \text {. Final time } \\
\text { point TL reduced in endurance athletes compared to baseline }(p=0.0006) \text {. }\end{array}$ \\
\hline [269] & 477 healthy males and females & Leukocytes & $\mathrm{T} / \mathrm{S} \mathrm{qPCR}$ & Vigorous PA positively associated with LTL $(p<0.01)$. \\
\hline [270] & 814 participants: 397 males, 417 females & Leukocytes & $\mathrm{T} / \mathrm{S} \mathrm{qPCR}$ & $\begin{array}{l}\text { LTL longer in participants: currently exercising compared to inactive ( } p=0.013) \text {, engaged in } \\
\text { intensive activity }(p=0.011) \text {, participating in sport for } 10 \text { years prior to assessment }(p=0.017) \text {. }\end{array}$ \\
\hline [271] & 1476 older aged white and African American women & Leukocyte & Southern blot TRF & $\begin{array}{l}\text { Highest self-reported PA associated with longer LTL compared to lowest PA ( } p=0.02) \text {. } \\
\text { Higher levels of moderate-to-vigorous PA ( } p=0.04) \text { and faster walking speed }(p=0.03) \\
\text { associated with longer LTL. }\end{array}$ \\
\hline [272] & 582 older adults & Leukocytes & Southern blot TRF & $\begin{array}{l}\text { Greater walking distance }(p=0.007) \text { and better chair test performance }(p=0.04) \text { associated with } \\
\text { longer LTL cross-sectionally. Change in chair test performance associated with less LTL } \\
\text { shortening longitudinally }(p=0.04) \text {. }\end{array}$ \\
\hline
\end{tabular}

CHD: coronary heart disease. CVD: cardiovascular disease. FlowFISH: fluorescence in situ hybridization combined with flow cytometry. TL: telomere length. LTL: leukocyte telomere length. PA: physical activity. PBMCs: Peripheral blood mononuclear cells. TRF: terminal restriction fragment analysis. TRFL: terminal restriction fragment length. T/S qPCR: the ratio of telomere PCR value to single-copy gene value derived from quantitative PCR. SD: standard deviation. SES: socio-economic status. $\mathrm{VO}_{2 \text { max: }}$ maximal volume of oxygen uptake. 
Table 2. A summary of studies showing no association between physical activity and telomere length.

\begin{tabular}{|c|c|c|c|c|}
\hline Ref. & Subjects $(n)$ & Tissue & Measurement & Key Findings \\
\hline [15] & 2509 participants: males $(n=1218)$, females $(n=1291)$ & Leukocytes & Southern blot TRF & Self-reported PA not associated with LTL $(p=0.806)$. \\
\hline [89] & 608 individuals with stable CAD: 244 males, 364 females & Leukocytes & $\mathrm{T} / \mathrm{S}$ qPCR & PA did not independently modulate LTL $(p=0.59)$. \\
\hline [95] & 4576 male and female Danish participants & Leukocytes & T/S qPCR & Change in LTL over 10 years not associated with PA $(p=0.85)$ \\
\hline [273] & 612 advanced prostate cancer cases 1049 age-matched controls & Leukocytes & $\mathrm{T} / \mathrm{S} \mathrm{qPCR}$ & $\begin{array}{l}\text { No significant association between PA and LTL in all subjects combined }(p=0.262) \text {. } \\
\text { LTL positively associated with healthy lifestyle factors (e.g., diet, PA, smoking) }(p=0.004) \text {. }\end{array}$ \\
\hline [250] & $\begin{array}{l}17 \text { marathon runners } \\
15 \text { age- and sex-matched sedentary controls }\end{array}$ & $\begin{array}{l}\text { Lymphocytes } \\
\text { and granulocytes }\end{array}$ & $\mathrm{T} / \mathrm{S} \mathrm{qPCR}$ & $\begin{array}{l}\text { No significant difference between marathon runner lymphocyte TL }(p=0.6) \text { and } \\
\text { granulocyte }(p=0.9) \text { compared to controls. }\end{array}$ \\
\hline [251] & 18 experienced runners, 19 sedentary individuals & Skeletal muscle & Southern blot TRF & $\begin{array}{l}\text { No significant difference in minimum TRF between runners and sedentary }(p=0.805) \text {. } \\
\text { Minimum TRF within runners inversely related to years of running }(p=0.007) \text { and hours } \\
\text { spent training }(p=0.035) \text {. }\end{array}$ \\
\hline [252] & $\begin{array}{l}439 \text { overweight and obese women } \\
\text { Randomized into: dietary weight loss }(n=118) \text {, aerobic exercise } \\
(n=117) \text {, diet and exercise }(n=117) \text {, control }(n=87)\end{array}$ & Leukocytes & $\mathrm{T} / \mathrm{S} \mathrm{qPCR}$ & $\begin{array}{l}\text { No significant difference in LTL in exercise group }(p=0.51) \text {, diet and exercise group } \\
(p=0.14) \text {. } \\
\text { Baseline LTL positively associated with } \mathrm{VO}_{2 \max }(p=0.03) .\end{array}$ \\
\hline [253] & 2284 women (Nurses' Health Study) & Leukocyte & $\mathrm{T} / \mathrm{S} \mathrm{qPCR}$ & No association between LTL and PA $(p=0.69)$. \\
\hline [255] & 981 individuals: 467 males, 514 females & Leukocytes & $\mathrm{T} / \mathrm{S} \mathrm{qPCR}$ & Work related PA not associated with LTL $(p=0.933)$ \\
\hline [256] & $\begin{array}{l}521 \text { obese individuals randomized into: } 2 \text { Mediterranean diet } \\
\text { groups, } 1 \text { low-fat control group }\end{array}$ & Leukocytes & $\mathrm{T} / \mathrm{S} \mathrm{qPCR}$ & Self-reported PA not associated with telomere length ( $p=0.186$ ). \\
\hline [257] & 190 subjects with impaired glucose tolerance, 188 controls & Leukocytes & $\mathrm{T} / \mathrm{S} \mathrm{qPCR}$ & $\begin{array}{l}\text { No significant difference in LTL following multi-faceted lifestyle intervention at } 4.5 \text { years } \\
\text { follow up }(p=0.76) \text {. }\end{array}$ \\
\hline [258] & 14 individuals, 7 powerlifters, 7 healthy controls & Skeletal muscle & Southern blot TRF & TL not significantly associated with $8 \pm 3$ years of powerlifting experience $(p=0.07)$. \\
\hline [259] & $\begin{array}{l}599 \text { healthy males: } \\
392 \text { former athletes, } 207 \text { controls }\end{array}$ & Leukocytes & $\mathrm{T} / \mathrm{S} \mathrm{qPCR}$ & $\begin{array}{l}\text { No association between self-reported volume of leisure time PA and LTL in later life } \\
(p=0.845) .\end{array}$ \\
\hline [261] & $\begin{array}{l}42 \text { participants: } 10 \text { young males, } 6 \text { young females, } 13 \text { old males, } \\
13 \text { old females }\end{array}$ & Skeletal muscle & Southern blot TRF & $\begin{array}{l}\text { Tibialis anterior telomere length not significantly influenced by self-reported PA } \\
\text { ( } p \text { value not available). }\end{array}$ \\
\hline [262] & $\begin{array}{l}16 \text { obese middle-aged women randomized into: exercise group, } \\
\text { control group }\end{array}$ & Leukocytes & $\mathrm{T} / \mathrm{S} \mathrm{qPCR}$ & No significant change in LTL after 6 months of aerobic training. \\
\hline [263] & 136 participants: 50 males, 86 females & Lymphocytes & $\mathrm{T} / \mathrm{S} \mathrm{qPCR}$ & Self-reported PA not associated with longer TL $(p=0.4570)$. \\
\hline [264] & 5862 women & Leukocytes & $\mathrm{T} / \mathrm{S} \mathrm{qPCR}$ & $\begin{array}{l}\text { No association between PA and LTL. Presence of five low-risk healthy lifestyle factors } \\
\text { associated with longer LTL }(p=0.015) \text {. }\end{array}$ \\
\hline [265] & 1942 male and female participants & Leukocytes & $\mathrm{T} / \mathrm{S}$ qPCR & PA not significantly associated with LTL in males or females ( $p$-value not available) \\
\hline [266] & 2006 Chinese participants: male $(n=976)$, female $(n=1030)$ & Leukocytes & $\mathrm{T} / \mathrm{S} \mathrm{qPCR}$ & No significant difference in TL across quartiles of self-reported PA $(p=0.32)$ \\
\hline [274] & $\begin{array}{l}\text { 84 Caucasian individuals distributed into two groups: } \\
\text { exercise trained }(n=44) \text {, recreationally active controls }(n=40)\end{array}$ & PBMCs & $\mathrm{T} / \mathrm{S} \mathrm{qPCR}$ & $\begin{array}{l}\text { No significant difference in PBMC telomere length between exercising group and controls } \\
(p=0.72) \text {. }\end{array}$ \\
\hline [275] & 203 healthy participants; African $(n=96)$, Caucasian $(n=107)$ & Leukocytes & $\mathrm{T} / \mathrm{S} \mathrm{qPCR}$ & Habitual PA not associated with LTL. \\
\hline
\end{tabular}

T/S qPCR: the ratio of telomere PCR value to single-copy gene value derived from quantitative PCR. $\mathrm{VO}_{2 \text { max }}$ maximal volume of oxygen uptake. 


\section{Proposed Mechanisms}

Despite the positive associations between habitual PA and LTL, a clear mechanistic understanding of telomeric adaptation is lacking. Following is a summary of the more widely held mechanistic theories and some candidate mechanisms still subject to further investigation. For a detailed review of other candidate molecules and signaling pathways, readers should seek out the relevant reviews [21].

\section{Telomerase and Physical Activity}

Longer telomeres are often inferred by increased telomerase activity; however, levels do not reliably correlate with telomere length [276]. In a study of 124 health individuals, telomerase activity progressively decreased in concert with telomere length from ages 4 to 39 years. However, $65 \%$ of individuals aged 40 years or older exhibited low yet stable telomerase expression despite continued telomere shortening [277].

Mouse models have demonstrated exercise-induced telomerase increases [247,278-280]; however, human results are conflicting. In one study, there was no difference in peripheral blood mononuclear cell (PBMC) telomerase expression between physical fitness categories [241]. Yet in another study, endurance-trained athletes demonstrated increased leukocyte telomerase compared to controls [247]. A 3 month multifaceted intervention consisting of diet, exercise and stress management techniques increased PBMC telomerase expression; however, direct causation cannot be assigned to one specific modality [281]. Whilst some interventional studies using acute and intensive exercise interventions failed to increase leukocyte telomerase expression [260], a recent study elicited increased PBMC telomerase expression after a single bout of treadmill running [282]. Exercise-induced increases in $h T E R T$ mRNA have been observed; however, a correlation with telomerase enzyme activity can only be inferred [283].

Telomerase preferentially targets short telomeres [284], therefore acute increases in telomerase may be an attempt to stabilize critically shortened telomeres [285]. This may explain the increased telomerase activity and shortened telomeres that accompany subclinical coronary atherosclerosis [286].

\section{Oxidative Stress}

The accumulation of oxidative stress-induced DNA damage is a key factor in cellular dysfunction and organismal aging [287], neurodegeneration [288,289], atherosclerosis, diabetes [290] and carcinogenesis [291]. Telomeric DNA is particularly susceptible to oxidative damage due to the telomeric G triplet [14,292-294]. Chronic oxidative stress decreases telomeric DNA repair mechanisms [295], resulting in cumulative and irreparable damage [35]. In doing so, telomeres chronicle chronic exposure to oxidative stress [296].

Paradoxically, mild exposure to oxidative stress serves a telomere protective function by increasing anti-oxidant defense systems [262,297-301] and enhancing oxidative damage repair systems [302]. Cellular antioxidant capacity is correlated with cellular proliferative capacity and telomere attrition rate [303]. Overexpression of superoxide dismutase reduces telomere shortening in human fibroblasts [304]. Additionally, under conditions of oxidative stress, telomerase translocates to the mitochondria where it appears to play a protective function $[305,306]$. The association between habitual moderate intensity exercise and longer telomeres $[223,273]$ may be mediated by an exercise-induced increase in antioxidant defenses. However, a study of obese middle-aged women demonstrated increases in antioxidant enzymes without concomitant changes in LTL [262].

\section{Inflammation}

The PA-mediated attenuation of chronic inflammation likely underpins the protective effect of PA on LTL. Chronic inflammation causes hematopoietic stem cell activation and subsequent WBC turnover resulting in telomere attrition [307]. Shortened LTL have been associated with elevated concentrations of pro-inflammatory cytokines interleukin (IL)-6 and tumor necrosis factor 
(TNF)- $\alpha$ [308]. Chronic inflammation can also elicit replicative senescence, oxidative stress and modulation of telomerase activity [309-313]. Shorter mean LTL may reflect an increased burden of senescent cells which are known to create a pro-inflammatory phenotype [314,315]. Despite the association, chronic inflammation levels but not LTL predicted successful aging in a cohort of 1554 centenarian, supercentenarians and very old individuals [228].

A consistent inverse association is seen between habitual PA and chronic inflammation [316,317]. The inverted " $U$ " response of telomere homeostasis identified in some studies may be partially explained by the hormetic inflammatory and oxidative stress response to exercise [318,319]. Whether PA decreases inflammation and subsequent telomere attrition or decreases telomere attrition, therefore forestalling the onset of senescence-mediated inflammation, remains an open question.

\section{The Shelterin Complex}

Mouse models have demonstrated exercise-induced plasticity of shelterin components including Trf2 mRNA [279] and skeletal muscle Trf1 mRNA [320]. Human studies, mostly observational, have identified increased TRF2 mRNA and protein in young and middle-aged athletes compared to controls [247]. Increased mRNA expression of leukocyte adrenocortical dysplasia homolog (TPP1) and hTERT mRNA was also observed in athletes compared to controls [254]. Athletes who performed seven marathons in one week demonstrated upregulated DNA damage repair enzymes Ku70 and Ku80 in addition to increased TRF1, TRF2 and Pot-1 mRNA expression. This occurred without concomitant changes in telomere length or telomerase activity [260]. A single $30 \mathrm{~min}$ bout of treadmill running upregulated WBC hTERT and telomeric repeat binding factor 2 (TERF2IP) mRNA expression in healthy males [283]. Whilst highly plausible mechanisms, these observations do not infer causation.

\section{Epigenetics and Telomere Homeostasis}

Telomere length is influenced by a host of epigenetic factors including methylation of sub telomeric DNA [321-323], histone modification [324,325], posttranslational modifications of shelterin components [326,327] and non-coding RNAs [328]. An in-depth review of all proposed epigenetic pathways is beyond the scope of this review. What follows is a brief overview of the current evidence.

MicroRNAs (miRNAs) play critical roles in modulating gene expression via translational repression or total degradation of the target mRNA [329] MiRNAs mediate several exercise adaptations [330-334] and demonstrate exercise-induced expression profiles in leukocyte subsets [335-339]. Exercise-induced increases in WBC miR-186 and miR-96 expression were observed after a 30-min exercise bout [283]. In silico analysis identified TERF2IP as a potential regulatory target of miR-186 and miR-96. Telomeric repeat factor 1 is translationally repressed by miR-155 resulting in chromosome alterations and telomere fragility [328]. Animal models indicate that miR-155 expression decreases in response to exercise [340]. Expression of TERT mRNA is regulated by miR-498 [341]; however, little is known about the exercise responsiveness of miR-498.

A clear understanding of the role of miRNA-mediated telomere homeostasis is still in its infancy. The direction of the miRNA-telomere interaction is currently unclear; telomere shortening may actually cause differential miRNA expression [342]. Most of the established miRNA-telomere associations have been observed in cancer cell lines, wherein dysregulated telomere maintenance mechanisms may have corrupted the observed associations. To gain a causal understanding of the role of miRNAs in telomere homeostasis, gain/loss of function experiments must be conducted in cell lines and animal models.

Accumulating evidence indicates that global DNA methylation may regulate telomere length variability in adults $[343,344]$. Associations between DNA methylation and telomere length were initially established in mice [345]; subsequent human studies identified a positive association between global DNA methylation at proximal sub telomeric regions and telomerase activity [346]. Little is currently known about exercise-induced methylation changes within telomeres.

Human telomeres have long been considered transcriptionally silent; however, recent evidence indicates they are transcribed by RNA polymerase II, producing a class of long noncoding RNA 
(lncRNA) containing telomeric repeats called TERRA [347,348]. TERRA molecules are displaced from telomeres and recruited to chromosomal ends through interaction with the telomeric structure, including shelterin components TRF1 and TRF2 [349]. TERRA also interacts with telomeres via the formation of RNA:DNA hybrid structures known as R-loops [350-353], which are involved with gene expression regulation [354] and transcription termination [355]. In shortened or damaged telomeres, TERRA is observed in increased levels [356-358]. Upregulation of TERRA is also observed in instances of DNA damage or loss of TRF2 [358]. With so much still to learn about lncRNAs such as TERRA, a full understanding of their potential telomere-regulatory role is several years away.

\section{Conclusions}

The proposed associations with aging and exercise are biologically plausible. Telomere length holds tantalizing promise as a biomarker; however, a host of evidential inconsistencies and paradoxes must be addressed. Leukocyte telomere length is highly variable at birth, a metric influenced by genetic inheritance and paternal age at conception. It reflects lifelong exposure to oxidative and inflammatory burden yet childhood LTL has more predictive fidelity than LTL in adulthood or old age. Oscillating throughout the lifespan, even inexplicably lengthening despite advancing age, mean LTL differs between genders. Attrition rates also differ between genders and appear dependent upon initial telomere length. Shortening trajectories can be further influenced by variable exposure to a wide range of environmental stimuli. The association between PA is more questionable with $50 \%$ of studies failing to find a significant association.

Investigations into plausible mechanisms have returned promising yet inconsistent findings. The prevailing consensus is that exercise-induced reductions in oxidative stress and inflammation likely mediate the effect. The possibility that LTL is a physiological epiphenomenon cannot be excluded. Changes in LTL may simply be coincidental processes that reflect, without directly influencing, the primary mechanism. It is likely that telomere length per se is significant only in so much as it reflects the resultant phenotype via pathways such as senescence-associated inflammation.

It has been proposed that evolutionary pressures have fine-tuned telomere length to reduce the risk of short and long telomere pathologies, namely atherosclerosis and cancer [359-361]. The long-term consequences of manipulating telomere length are not well understood and should therefore be approached with equal measures of enthusiasm and evidence.

\section{Future Directions}

Telomere and telomerase research is on the brink of truly significant contributions to human health and disease management. Exciting associations and plausible putative mechanisms seem to promise therapeutic targets for the future. The extensive associations strongly imply causal involvement and warrant closer, more detailed analysis. We propose four general areas of future research direction.

First, evidence of actual telomere lengthening is lacking. Whether an individual can move from the lowest to the highest quartile of LTL through lifestyle interventions, presumably with an enhanced phenotype, remains an open and essential question. Given the propensity for LTL to track through the lifespan [82], the capacity of PA to modulate a seemingly centrally-driven measure must be addressed. If actual telomere lengthening is identified, it must then be determined whether such lengthening lies within the considerable natural ebb and flow of telomere length dynamics over time.

The second future direction regards selection of the most relevant telomeric metric. Evidence suggests that the proportion of short telomeres may be more consequential than mean LTL given the ability of very long telomeres within a cell to skew the mean $[362,363]$. Studies reporting longer LTL in the physically active should also report the relative proportion of the shortest telomeres.

The third future direction regards the use of mediation analysis to quantify positive and negative telomere instigators. Mediation analysis models a hypothesized causal chain in which a variable of interest influences an intervening mediator variable which in turn mediates the outcome variable. This allows the effect of exposure to the mediator on the outcome variable. Mediation analysis 
quantifies the exposure of likely mediating factors such as oxidative stress, inflammation and age. Analysis of this sort would also reveal whether changes in telomere length can occur independently of factors like oxidative stress and inflammation. As an example, a recent study found that fasting insulin partially mediates the association between genetically determined LTL and CHD risk [364].

The final proposed direction is the development of a regularly updated international consensus document on telomere research methodology. Developed by an international consortium of leading telomere researchers, this document could outline: (i) preferred measurement techniques; (ii) acceptable coefficients of variation; (iii) universally accepted definitions and criteria for long and short telomeres and (iv) rigorous methods of data interpretation. In time, publishing in accordance with such guidelines would become the standard expectation with reputational costs incurred for discrepant methodologies.

Many exciting discoveries are undoubtedly yet to come from the field; however, many of these may be lost to unacceptably large measurement variations and inconsistent methodologies. The irresistible logicality of the reported telomeric associations risks the premature inference of causation. The final quantum leap to be made will be the translation of benchtop findings into clinically relevant interventions. Only then will the ends have justified the means.

Author Contributions: Warrick Chilton conceived and composed this manuscript. Fadi Charchar and Brendan O'Brien edited and commented upon the final draft. All authors reviewed the manuscript.

Conflicts of Interest: The authors declare no conflict of interest.

\section{References}

1. United-Nations. World Population Ageing 2015. Available online: http://www.un.org/en/development/ desa/population/publications/index.shtml (accessed on 7 March 2017).

2. Murray, C.J.L.; Barber, R.M.; Foreman, K.J.; Ozgoren, A.A.; Abd-Allah, F.; Abera, S.F.; Aboyans, V.; Abraham, J.P.; Abubakar, I.; Abu-Raddad, L.J.; et al. Global, regional and national disability-adjusted life years (DALYs) for 306 diseases and injuries and healthy life expectancy (HALE) for 188 countries, 1990-2013: Quantifying the epidemiological transition. Lancet 2015, 386, 2145-2191. [PubMed]

3. Strihler, B. Times, Cells and Aging; Academic Press: New York, NY, USA, 1962.

4. Lowsky, D.J.; Olshansky, S.J.; Bhattacharya, J.; Goldman, D.P. Heterogeneity in healthy aging. J. Gerontol. Ser. A Biol. Sci. Med. Sci. 2014, 69, 640-649.

5. Prospective Studies Collaboration. Body-mass index and cause-specific mortality in 900,000 adults: Collaborative analyses of 57 prospective studies. Lancet 2009, 373, 1083-1096.

6. Brown, L.; Needham, B.; Ailshire, J. Telomere length among older U.S. Adults: Differences by race/ethnicity, gender and age. J. Aging Health 2016, 29, 1350-1366.

7. Needham, B.L.; Adler, N.; Gregorich, S.; Rehkopf, D.; Lin, J.; Blackburn, E.H.; Epel, E.S. Socioeconomic status, health behavior and leukocyte telomere length in the national health and nutrition examination survey, 1999-2002. Soc. Sci. Med. 2013, 85, 1-8. [PubMed]

8. De Lange, T. Shelterin: The protein complex that shapes and safeguards human telomeres. Genes Dev. 2005, 19, 2100-2110. [PubMed]

9. Olovnikov, A.M. Principle of marginotomy in template synthesis of polynucleotides. Dokl. Akad. Nauk SSSR 1971, 201, 1496-1499. [PubMed]

10. Watson, J.D. Origin of concatemeric T7 DNA. Nat. New Biol. 1972, 239, 197-201. [PubMed]

11. Griffith, J.D.; Comeau, L.; Rosenfield, S.; Stansel, R.M.; Bianchi, A.; Moss, H.; de Lange, T. Mammalian telomeres end in a large duplex loop. Cell 1999, 97, 503-514. [PubMed]

12. Greider, C.W.; Blackburn, E.H. The telomere terminal transferase of tetrahymena is a ribonucleoprotein enzyme with two kinds of primer specificity. Cell 1987, 51, 887-898. [PubMed]

13. Blackburn, E.H.; Greider, C.W.; Henderson, E.; Lee, M.S.; Shampay, J.; Shippen-Lentz, D. Recognition and elongation of telomeres by telomerase. Genome 1989, 31, 553-560. [PubMed]

14. Von Zglinicki, T. Role of oxidative stress in telomere length regulation and replicative senescence. Ann. N. Y. Acad. Sci. 2000, 908, 99-110. [PubMed] 
15. Bekaert, S.; De Meyer, T.; Rietzschel, E.R.; De Buyzere, M.L.; de Bacquer, D.; Langlois, M.; Segers, P.; Cooman, L.; van Damme, P.; Cassiman, P. Telomere length and cardiovascular risk factors in a middle-aged population free of overt cardiovascular disease. J. Anat. 2007, 6, 639-647.

16. Vasan, R.S.; Demissie, S.; Kimura, M.; Cupples, L.A.; Rifai, N.; White, C.; Wang, T.J.; Gardner, J.P.; Cao, X.; Benjamin, E.J.; et al. Association of leukocyte telomere length with circulating biomarkers of the renin-angiotensin-aldosterone system: The framingham heart study. Circulation 2008, 117, 1138-1144. [PubMed]

17. Valdes, A.M.; Andrew, T.; Gardner, J.P.; Kimura, M.; Oelsner, E.; Cherkas, L.F.; Aviv, A.; Spector, T.D. Obesity, cigarette smoking and telomere length in women. Lancet 2005, 366, 662-664. [PubMed]

18. Harris, S.E.; Deary, I.J.; MacIntyre, A.; Lamb, K.J.; Radhakrishnan, K.; Starr, J.M.; Whalley, L.J.; Shiels, P.G. The association between telomere length, physical health, cognitive ageing and mortality in non-demented older people. Neurosci. Lett. 2006, 406, 260-264. [PubMed]

19. Puterman, E.; Lin, J.; Blackburn, E.; O’Donovan, A.; Adler, N.; Epel, E. The power of exercise: Buffering the effect of chronic stress on telomere length. PLOS ONE 2010, 5, e10837.

20. Cherkas, L.F.; Hunkin, J.L.; Kato, B.S.; Richards, J.B.; Gardner, J.P.; Surdulescu, G.L.; Kimura, M.; Lu, X.; Spector, T.D.; Aviv, A. The association between physical activity in leisure time and leukocyte telomere length. Arch. Intern. Med. 2008, 168, 154-158. [PubMed]

21. Ludlow, A.T.; Ludlow, L.W.; Roth, S.M. Do telomeres adapt to physiological stress? Exploring the effect of exercise on telomere length and telomere-related proteins. BioMed Res. Int. 2013, 2013, 15.

22. Mather, K.A.; Jorm, A.F.; Parslow, R.A.; Christensen, H. Is telomere length a biomarker of aging? A review. J. Gerontol. Ser. A 2011, 66, 202-213.

23. Hayflick, L.; Moorhead, P.S. The serial cultivation of human diploid cell strains. Exp. Cell Res. 1961, 25, 585-621. [CrossRef]

24. Ritschka, B.; Storer, M.; Mas, A.; Heinzmann, F.; Ortells, M.C.; Morton, J.P.; Sansom, O.J.; Zender, L.; Keyes, W.M. The senescence-associated secretory phenotype induces cellular plasticity and tissue regeneration. Genes Dev. 2017, 31, 172-183. [CrossRef] [PubMed]

25. Acosta, J.C.; Banito, A.; Wuestefeld, T.; Georgilis, A.; Janich, P.; Morton, J.P.; Athineos, D.; Kang, T.-W.; Lasitschka, F.; Andrulis, M.; et al. A complex secretory program orchestrated by the inflammasome controls paracrine senescence. Nat. Cell Biol. 2013, 15, 978-990. [CrossRef] [PubMed]

26. Munoz-Espin, D.; Canamero, M.; Maraver, A.; Gomez-Lopez, G.; Contreras, J.; Murillo-Cuesta, S.; Rodriguez-Baeza, A.; Varela-Nieto, I.; Ruberte, J.; Collado, M.; et al. Programmed cell senescence during mammalian embryonic development. Cell 2013, 155, 1104-1118. [CrossRef] [PubMed]

27. Bhatia-Dey, N.; Kanherkar, R.R.; Stair, S.E.; Makarev, E.O.; Csoka, A.B. Cellular senescence as the causal nexus of aging. Front. Genet. 2016, 7. [CrossRef] [PubMed]

28. Demaria, M.; O’Leary, M.N.; Chang, J.; Shao, L.; Liu, S.; Alimirah, F.; Koenig, K.; Le, C.; Mitin, N.; Deal, A.M.; et al. Cellular senescence promotes adverse effects of chemotherapy and cancer relapse. Cancer Discov. 2017, 7, 165-176. [CrossRef] [PubMed]

29. Campisi, J. Cellular senescence as a tumor-suppressor mechanism. Trends Cell Biol. 2001, 11, S27-S31. [CrossRef]

30. Harley, C.B.; Futcher, A.B.; Greider, C.W. Telomeres shorten during ageing of human fibroblasts. Nature 1990, 345, 458-460. [CrossRef] [PubMed]

31. Artandi, S.E.; Attardi, L.D. Pathways connecting telomeres and p53 in senescence, apoptosis and cancer. Biochem. Biophys. Res. Commun. 2005, 331, 881-890. [CrossRef] [PubMed]

32. Alcorta, D.A.; Xiong, Y.; Phelps, D.; Hannon, G.; Beach, D.; Barrett, J.C. Involvement of the cyclin-dependent kinase inhibitor p16 (INK4A) in replicative senescence of normal human fibroblasts. Proc. Natl. Acad. Sci. USA 1996, 93, 13742-13747. [CrossRef] [PubMed]

33. Rodier, F.; Muñoz, D.P.; Teachenor, R.; Chu, V.; Le, O.; Bhaumik, D.; Coppé, J.-P.; Campeau, E.; Beauséjour, C.M.; Kim, S.-H.; et al. DNA-scars: Distinct nuclear structures that sustain damage-induced senescence growth arrest and inflammatory cytokine secretion. J. Cell Sci. 2011, 124, 68-81. [CrossRef] [PubMed]

34. Takahashi, A.; Ohtani, N.; Yamakoshi, K.; Iida, S.; Tahara, H.; Nakayama, K.; Nakayama, K.I.; Ide, T.; Saya, H.; Hara, E. Mitogenic signaling and the p16ink4a-Rb pathway cooperate to enforce irreversible cellular senescence. Nat. Cell Biol. 2006, 8, 1291-1297. [CrossRef] [PubMed] 
35. Fumagalli, M.; Rossiello, F.; Clerici, M.; Barozzi, S.; Cittaro, D.; Kaplunov, J.M.; Bucci, G.; Dobreva, M.; Matti, V.; Beausejour, C.M.; et al. Telomeric DNA damage is irreparable and causes persistent DNA-damage-response activation. Nat. Cell Biol. 2012, 14, 355-365. [CrossRef] [PubMed]

36. Zhou, X.; Perez, F.; Han, K.; Jurivich, D.A. Clonal senescence alters endothelial icam-1 function. Mech. Ageing Dev. 2006, 127, 779-785. [CrossRef] [PubMed]

37. Minamino, T.; Orimo, M.; Shimizu, I.; Kunieda, T.; Yokoyama, M.; Ito, T.; Nojima, A.; Nabetani, A.; Oike, Y.; Matsubara, H.; et al. A crucial role for adipose tissue p53 in the regulation of insulin resistance. Nat. Med. 2009, 15, 1082-1087. [CrossRef] [PubMed]

38. Shimizu, I.; Yoshida, Y.; Katsuno, T.; Tateno, K.; Okada, S.; Moriya, J.; Yokoyama, M.; Nojima, A.; Ito, T.; Zechner, R.; et al. P53-induced adipose tissue inflammation is critically involved in the development of insulin resistance in heart failure. Cell Metab. 2012, 15, 51-64. [CrossRef] [PubMed]

39. Martin, J.A.; Brown, T.D.; Heiner, A.D.; Buckwalter, J.A. Chondrocyte senescence, joint loading and osteoarthritis. Clin. Orthop. Relat. Res. 2004, 427, S96-S103. [CrossRef]

40. Liton, P.B.; Challa, P.; Stinnett, S.; Luna, C.; Epstein, D.L.; Gonzalez, P. Cellular senescence in the glaucomatous outflow pathway. Exp. Gerontol. 2005, 40, 745-748. [CrossRef] [PubMed]

41. Baker, D.; Wijshake, T.; Tchkonia, T.; LeBrasseur, N.; Childs, B.; van de Sluis, B.; Kirkland, J.; van Deursen, J. Clearance of p16ink4a-positive senescent cells delays ageing-associated disorders. Nature 2011, 479, 232-236. [CrossRef] [PubMed]

42. Van Deursen, J.M. The role of senescent cells in ageing. Nature 2014, 509, 439-446. [CrossRef] [PubMed]

43. Coppé, J.-P.; Desprez, P.-Y.; Krtolica, A.; Campisi, J. The senescence-associated secretory phenotype: The dark side of tumor suppression. Ann. Rev. Pathol. 2010, 5, 99-118. [CrossRef] [PubMed]

44. Thangavel, C.; Dean, J.L.; Ertel, A.; Knudsen, K.E.; Aldaz, C.M.; Witkiewicz, A.K.; Clarke, R.; Knudsen, E.S. Therapeutically activating RB: Reestablishing cell cycle control in endocrine therapy-resistant breast cancer. Endocr. Relat. Cancer 2011, 18, 333-345. [CrossRef] [PubMed]

45. Castle, S.C.; Uyemuraabc, K.; Crawford, W.; Wongab, W.; Klaustermeyer, W.B.; Makinodan, T. Age-related impaired proliferation of peripheral blood mononuclear cells is associated with an increase in both IL-10 and IL-12. Exp. Gerontol. 1999, 34, 243-252. [CrossRef]

46. Froelich, C.J.; Burkett, J.S.; Guiffaut, S.; Kingsland, R.; Brauner, D. Phytohemagglutinin induced proliferation by aged lymphocytes: Reduced expression of high affinity interleukin-2 receptors and interleukin-2 secretion. Life Sci. 1988, 43, 1583-1590. [CrossRef]

47. Effros, R.B.; Allsopp, R.; Chiu, C.P.; Hausner, M.A.; Hirji, K.; Wang, L.; Harley, C.B.; Villeponteau, B.; West, M.D.; Giorgi, J.V. Shortened telomeres in the expanded CD28-CD8+ cell subset in HIV disease implicate replicative senescence in HIV pathogenesis. AIDS 1996, 10, F17-F22. [CrossRef] [PubMed]

48. Franceschi, C.; Bonafè, M.; Valensin, S. Human immunosenescence: The prevailing of innate immunity, the failing of clonotypic immunity and the filling of immunological space. Vaccine 2000, 18, 1717-1720. [CrossRef]

49. Franceschi, C.; Capri, M.; Monti, D.; Giunta, S.; Olivieri, F.; Sevini, F.; Panourgia, M.P.; Invidia, L.; Celani, L.; Scurti, M.; et al. Inflammaging and anti-inflammaging: A systemic perspective on aging and longevity emerged from studies in humans. Mech. Ageing Dev. 2007, 128, 92-105. [CrossRef] [PubMed]

50. Targonski, P.V.; Jacobson, R.M.; Poland, G.A. Immunosenescence: Role and measurement in influenza vaccine response among the elderly. Vaccine 2007, 25, 3066-3069. [CrossRef] [PubMed]

51. Allsopp, R.C.; Vaziri, H.; Patterson, C.; Goldstein, S.; Younglai, E.V.; Futcher, A.B.; Greider, C.W.; Harley, C.B. Telomere length predicts replicative capacity of human fibroblasts. Proc. Natl. Acad. Sci. USA 1992, 89, 10114-10118. [CrossRef] [PubMed]

52. Brosh, R.M., Jr.; von Kobbe, C.; Sommers, J.A.; Karmakar, P.; Opresko, P.L.; Piotrowski, J.; Dianova, I.; Dianov, G.L.; Bohr, V.A. Werner syndrome protein interacts with human flap endonuclease 1 and stimulates its cleavage activity. EMBO J. 2001, 20, 5791-5801. [CrossRef] [PubMed]

53. Crabbe, L.; Verdun, R.E.; Haggblom, C.I.; Karlseder, J. Defective telomere lagging strand synthesis in cells lacking wrn helicase activity. Science 2004, 306, 1951-1953. [CrossRef] [PubMed]

54. Crabbe, L.; Jauch, A.; Naeger, C.M.; Holtgreve-Grez, H.; Karlseder, J. Telomere dysfunction as a cause of genomic instability in werner syndrome. Proc. Natl. Acad. Sci. USA 2007, 104, 2205-2210. [CrossRef] [PubMed] 
55. Decker, M.L.; Chavez, E.; Vulto, I.; Lansdorp, P.M. Telomere length in hutchinson-gilford progeria syndrome. Mech. Ageing Dev. 2009, 130, 377-383. [CrossRef] [PubMed]

56. Johnson, T.E. Recent results: Biomarkers of aging. Exp. Gerontol. 2006, 41, 1243-1246. [CrossRef] [PubMed]

57. Simm, A.; Nass, N.; Bartling, B.; Hofmann, B.; Silber, R.-E.; Navarrete Santos, A. Potential biomarkers of ageing. Biol. Chem. 2008, 389, 257-265. [CrossRef] [PubMed]

58. Sanders, J.L.; Newman, A.B. Telomere length in epidemiology: A biomarker of aging, age-related disease, both, or neither? Epidemiol. Rev. 2013, 35, 112-131. [CrossRef] [PubMed]

59. Steenstrup, T.; Hjelmborg, J.V.; Kark, J.D.; Christensen, K.; Aviv, A. The telomere lengthening conundrum-Artifact or biology? Nucleic Acids Res. 2013, 41, e131. [CrossRef] [PubMed]

60. Andrew, T.; Aviv, A.; Falchi, M.; Surdulescu, G.L.; Gardner, J.P.; Lu, X.; Kimura, M.; Kato, B.S.; Valdes, A.M.; Spector, T.D. Mapping genetic loci that determine leukocyte telomere length in a large sample of unselected female sibling pairs. Am. J. Hum. Genet. 2006, 78, 480-486. [CrossRef] [PubMed]

61. Codd, V.; Mangino, M.; van der Harst, P.; Braund, P.S.; Kaiser, M.; Beveridge, A.J.; Rafelt, S.; Moore, J.; Nelson, C.; Soranzo, N. Common variants near TERC are associated with mean telomere length. Nat. Genet. 2010, 42, 197-199. [CrossRef] [PubMed]

62. Levy, D.; Neuhausen, S.L.; Hunt, S.C.; Kimura, M.; Hwang, S.; Chen, W.; Bis, J.C.; Fitzpatrick, A.L.; Smith, E.; Johnson, A.D.; et al. Genome-wide association identifies OBFC1 as a locus involved in human leukocyte telomere biology. Proc. Natl. Acad. Sci. USA 2010, 107, 9293-9298. [CrossRef] [PubMed]

63. Mangino, M.; Brouilette, S.; Braund, P.; Tirmizi, N.; Vasa-Nicotera, M.; Thompson, J.R.; Samani, N.J. A regulatory SNP of the BICD1 gene contributes to telomere length variation in humans. Hum. Mol. Genet. 2008, 17, 2518-2523. [CrossRef] [PubMed]

64. Mangino, M.; Richards, J.B.; Soranzo, N.; Zhai, G.; Aviv, A.; Valdes, A.M.; Samani, N.J.; Deloukas, P.; Spector, T.D. A genome-wide association sutdy identifies a novel locus on chromosome 18q12.2 influencing white cell telomere length. J. Med. Genet. 2009, 46, 451-454. [CrossRef] [PubMed]

65. Vasa-Nicotera, M.; Brouilette, S.; Mangino, M.; Thompson, J.R.; Braund, P.; Clemitson, J.-R.; Mason, A.; Bodycote, C.L.; Raleigh, S.M.; Louis, E.; et al. Mapping of a major locus that determines telomere length in humans. Am. J. Hum. Genet. 2005, 76, 147-151. [CrossRef] [PubMed]

66. Lansdorp, P.M.; Verwoerd, N.P.; van de Rijke, F.M.; Dragowska, V.; Little, M.T.; Dirks, R.W.; Raap, A.K.; Tanke, H.J. Heterogeneity in telomere length of human chromosomes. Hum. Mol. Genet. 1996, 5, 685-691. [CrossRef] [PubMed]

67. Martens, U.M.; Zijlmans, J.M.J.M.; Poon, S.S.S.; Dragowska, W.; Yui, J.; Chavez, E.A.; Ward, R.K.; Lansdorp, P.M. Short telomeres on human chromosome 17p. Nat. Genet. 1998, 18, 76-80. [CrossRef] [PubMed]

68. Müezzinler, A.; Zaineddin, A.K.; Brenner, H. A systematic review of leukocyte telomere length and age in adults. Ageing Res. Rev. 2013, 12, 509-519. [CrossRef] [PubMed]

69. Rode, L.; Nordestgaard, B.G.; Bojesen, S.E. Peripheral blood leukocyte telomere length and mortality among 64,637 individuals from the general population. J. Natl. Cancer Inst. 2015, 107, djv074. [CrossRef] [PubMed]

70. Tucker, L.A. Physical activity and telomere length in U.S. Men and women: An NHANES investigation. Prev. Med. 2017, 100, 145-151. [CrossRef] [PubMed]

71. Marioni, R.E.; Harris, S.E.; Shah, S.; McRae, A.F.; von Zglinicki, T.; Martin-Ruiz, C.; Wray, N.R.; Visscher, P.M.; Deary, I.J. The epigenetic clock and telomere length are independently associated with chronological age and mortality. Int. J. Epidemiol. 2016, 45, 424-432. [CrossRef] [PubMed]

72. De Meyer, T.; Rietzschel, E.R.; de Buyzere, M.L.; de Bacquer, D.; van Criekinge, W.; de Backer, G.G.; Gillebert, T.C.; van Oostveldt, P.; Bekaert, S. Paternal age at birth is an important determinant of offspring telomere length. Hum. Mol. Genet. 2007, 16, 3097-3102. [CrossRef] [PubMed]

73. Kimura, M.; Cherkas, L.F.; Kato, B.S.; Demissie, S.; Hjelmborg, J.B.; Brimacombe, M.; Cupples, A.; Hunkin, J.L.; Gardner, J.P.; Lu, X.; et al. Offspring's leukocyte telomere length, paternal age and telomere elongation in sperm. PLoS Genet. 2008, 4, e37. [CrossRef] [PubMed]

74. Broer, L.; Codd, V.; Nyholt, D.R.; Deelen, J.; Mangino, M.; Willemsen, G.; Albrecht, E.; Amin, N.; Beekman, M.; de Geus, E.J. Meta-analysis of telomere length in 19713 subjects reveals high heritability, stronger maternal inheritance and a paternal age effect. Eur. J. Hum. Genet. 2013, 21, 1163-1168. [CrossRef] [PubMed] 
75. Aviv, A.; Chen, W.; Gardner, J.P.; Kimura, M.; Brimacombe, M.; Cao, X.; Srinivasan, S.R.; Berenson, G.S. Leukocyte telomere dynamics: Longitudinal findings among young adults in the bogalusa heart study. Am. J. Epidemiol. 2009, 169, 323-329. [CrossRef] [PubMed]

76. Nordfjäll, K.; Svenson, U.; Norrback, K.-F.; Adolfsson, R.; Lenner, P.; Roos, G. The individual blood cell telomere attrition rate is telomere length dependent. PLoS Genet. 2009, 5, e1000375. [CrossRef] [PubMed]

77. Graakjaer, J.; Pascoe, L.; Der-Sarkissian, H.; Thomas, G.; Kolvraa, S.; Christensen, K.; Londoño-Vallejo, J.-A. The relative lengths of individual telomeres are defined in the zygote and strictly maintained during life. Aging Cell 2004, 3, 97-102. [CrossRef] [PubMed]

78. Aubert, G.; Baerlocher, G.M.; Vulto, I.; Poon, S.S.; Lansdorp, P.M. Collapse of telomere homeostasis in hematopoietic cells caused by heterozygous mutations in telomerase genes. PLoS Genet. 2012, 8, e1002696. [CrossRef] [PubMed]

79. Daniali, L.; Benetos, A.; Susser, E.; Kark, J.D.; Labat, C.; Kimura, M.; Desai, K.; Granick, M.; Aviv, A. Telomeres shorten at equivalent rates in somatic tissues of adults. Nat. Commun. 2013, 4, 1597. [CrossRef] [PubMed]

80. Sidorov, I.; Kimura, M.; Yashin, A.; Aviv, A. Leukocyte telomere dynamics and human hematopoietic stem cell kinetics during somatic growth. Exp. Hematol. 2009, 37, 514-524. [CrossRef] [PubMed]

81. Von Zglinicki, T.; Martin-Ruiz, C. Telomeres as biomarkers for ageing and age-related diseases. Curr. Mol. Med. 2005, 5, 197-203. [CrossRef] [PubMed]

82. Benetos, A.; Kark, J.D.; Susser, E.; Kimura, M.; Sinnreich, R.; Chen, W.; Steenstrup, T.; Christensen, K.; Herbig, U.; von Bornemann Hjelmborg, J.; et al. Tracking and fixed ranking of leukocyte telomere length across the adult life course. Aging Cell 2013, 12, 615-621. [CrossRef] [PubMed]

83. Verhulst, S.; Dalgård, C.; Labat, C.; Kark, J.D.; Kimura, M.; Christensen, K.; Toupance, S.; Aviv, A.; Kyvik, K.O.; Benetos, A. A short leucocyte telomere length is associated with development of insulin resistance. Diabetologia 2016, 59, 1258-1265. [CrossRef] [PubMed]

84. Grasman, J.; Salomons, H.M.; Verhulst, S. Stochastic modeling of length-dependent telomere shortening in corvus monedula. J. Theor. Biol. 2011, 282, 1-6. [CrossRef] [PubMed]

85. Hemann, M.T.; Strong, M.A.; Hao, L.-Y.; Greider, C.W. The shortest telomere, not average telomere length, is critical for cell viability and chromosome stability. Cell 2001, 107, 67-77. [CrossRef]

86. Martens, U.M.; Chavez, E.A.; Poon, S.S.S.; Schmoor, C.; Lansdorp, P.M. Accumulation of short telomeres in human fibroblasts prior to replicative senescence. Exp. Cell Res. 2000, 256, 291-299. [CrossRef] [PubMed]

87. Chen, W.; Kimura, M.; Kim, S.; Cao, X.; Srinivasan, S.R.; Berenson, G.S.; Kark, J.D.; Aviv, A. Longitudinal versus cross-sectional evaluations of leukocyte telomere length dynamics: Age-dependent telomere shortening is the rule. J. Gerontol. Ser. A 2011, 66, 312-319. [CrossRef] [PubMed]

88. Ehrlenbach, S.; Willeit, P.; Kiechl, S.; Willeit, J.; Reindl, M.; Schanda, K.; Kronenberg, F.; Brandstatter, A. Influences on the reduction of relative telomere length over 10 years in the population-based bruneck study: Introduction of a well-controlled high-throughput assay. Int. J. Epidemiol. 2009, 38, 1725-1734. [CrossRef] [PubMed]

89. Farzaneh-Far, R.; Lin, J.; Epel, E.; Lapham, K.; Blackburn, E.; Whooley, M.A. Telomere length trajectory and its determinants in persons with coronary artery disease: Longitudinal findings from the heart and soul study. PLoS ONE 2010, 5, e8612. [CrossRef] [PubMed]

90. Gardner, J.P.; Li, S.; Srinivasan, S.R.; Chen, W.; Kimura, M.; Lu, X.; Berenson, G.S.; Aviv, A. Rise in insulin resistance is associated with escalated telomere attrition. Circulation 2005, 111, 2171-2177. [CrossRef] [PubMed]

91. Houben, J.M.; Giltay, E.J.; Rius-Ottenheim, N.; Hageman, G.J.; Kromhout, D. Telomere length and mortality in elderly men: The zutphen elderly study. J. Gerontol. Ser. A Biol. Sci. Med. Sci. 2011, 66, 38-44. [CrossRef] [PubMed]

92. Kark, J.D.; Goldberger, N.; Kimura, M.; Sinnreich, R.; Aviv, A. Energy intake and leukocyte telomere length in young adults. Am. J. Clin. Nutr. 2012, 95, 479-487. [CrossRef] [PubMed]

93. Shalev, I.; Moffitt, T.E.; Sugden, K.; Williams, B.; Houts, R.M.; Danese, A.; Mill, J.; Arseneault, L.; Caspi, A. Exposure to violence during childhood is associated with telomere erosion from 5 to 10 years of age: A longitudinal study. Mol. Psychiatry 2013, 18, 576-581. [CrossRef] [PubMed]

94. Steenstrup, T.; Hjelmborg, J.V.; Mortensen, L.H.; Kimura, M.; Christensen, K.; Aviv, A. Leukocyte telomere dynamics in the elderly. Eur. J. Epidemiol. 2013, 28, 181-187. [CrossRef] [PubMed] 
95. Weischer, M.; Bojesen, S.E.; Nordestgaard, B.G. Telomere shortening unrelated to smoking, body weight, physical activity and alcohol intake: 4576 general population individuals with repeat measurements 10 years apart. PLoS Genet. 2014, 10, e1004191. [CrossRef] [PubMed]

96. Epel, E.S.; Merkin, S.S.; Cawthon, R.; Blackburn, E.H.; Adler, N.E.; Pletcher, M.J.; Seeman, T.E. The rate of leukocyte telomere shortening predicts mortality from cardiovascular disease in elderly men. Aging 2009, 1, 81-88. [CrossRef] [PubMed]

97. Svenson, U.; Nordfjäll, K.; Baird, D.; Roger, L.; Osterman, P.; Hellenius, M.-L.; Roos, G. Blood cell telomere length is a dynamic feature. PLOS ONE 2011, 6, e21485. [CrossRef] [PubMed]

98. Epel, E. How "reversible" is telomeric aging? Cancer Prev. Res. 2012, 5, 1163-1168. [CrossRef] [PubMed]

99. Minino, A.M.; Heron, M.P.; Murphy, S.L.; Kochanek, K.D. Deaths: Final data for 2004. Natl. Vital Stat. Rep. 2007, 55, 1-119. [PubMed]

100. Halaschek-Wiener, J.; Vulto, I.; Fornika, D.; Collins, J.; Connors, J.M.; Le, N.D.; Lansdorp, P.M.; Brooks-Wilson, A. Reduced telomere length variation in healthy oldest old. Mech. Ageing Dev. 2008, 129, 638-641. [CrossRef] [PubMed]

101. Martin-Ruiz, C.M.; Gussekloo, J.; van Heemst, D.; von Zglinicki, T.; Westendorp, R.G.J. Telomere length in white blood cells is not associated with morbidity or mortality in the oldest old: A population-based study. Aging Cell 2005, 4, 287-290. [CrossRef] [PubMed]

102. Simons, M.J.P. Questioning causal involvement of telomeres in aging. Ageing Res. Rev. 2015, 24, 191-196. [CrossRef] [PubMed]

103. Steenstrup, T.; Kark, J.D.; Verhulst, S.; Thinggaard, M.; Hjelmborg, J.V.B.; Dalgård, C.; Kyvik, K.O.; Christiansen, L.; Mangino, M.; Spector, T.D.; et al. Telomeres and the natural lifespan limit in humans. Aging 2017, 9, 1130-1140. [CrossRef] [PubMed]

104. Der, G.; Batty, G.D.; Benzeval, M.; Deary, I.J.; Green, M.J.; McGlynn, L.; McIntyre, A.; Robertson, T.; Shiels, P.G. Is telomere length a biomarker for aging: Cross-sectional evidence from the west of scotland? PLoS ONE 2012, 7, e45166. [CrossRef] [PubMed]

105. Mather, K.A.; Jorm, A.F.; Milburn, P.J.; Tan, X.; Easteal, S.; Christensen, H. No associations between telomere length and age-sensitive indicators of physical function in mid and later life. J. Gerontol. Ser. A Biol. Sci. Med. Sci. 2010, 65, 792-799. [CrossRef] [PubMed]

106. Brouilette, S.W.; Moore, J.S.; McMahon, A.D.; Thompson, J.R.; Ford, I.; Shepherd, J.; Packard, C.J.; Samani, N.J. Telomere length, risk of coronary heart disease and statin treatment in the west of scotland primary prevention study: A nested case-control study. Lancet 2007, 369, 107-114. [CrossRef]

107. Martin-Ruiz, C.; Jagger, C.; Kingston, A.; Collerton, J.; Catt, M.; Davies, K.; Dunn, M.; Hilkens, C.; Keavney, B.; Pearce, S.H.S.; et al. Assessment of a large panel of candidate biomarkers of ageing in the newcastle 85+ study. Mech. Ageing Dev. 2011, 132, 496-502. [CrossRef] [PubMed]

108. Boonekamp, J.J.; Simons, M.J.P.; Hemerik, L.; Verhulst, S. Telomere length behaves as biomarker of somatic redundancy rather than biological age. Aging Cell 2013, 12, 330-332. [CrossRef] [PubMed]

109. Armanios, M.; Blackburn, E.H. The telomere syndromes. Nat. Rev. Genet. 2012, 13, 693-704. [CrossRef] [PubMed]

110. Wilson, W.R.W.; Herbert, K.E.; Mistry, Y.; Stevens, S.E.; Patel, H.R.; Hastings, R.A.; Thompson, M.M.; Williams, B. Blood leucocyte telomere DNA content predicts vascular telomere DNA content in humans with and without vascular disease. Eur. Heart J. 2008, 29, 2689-2694. [CrossRef] [PubMed]

111. Friedrich, U.; Griese, E.; Schwab, M.; Fritz, P.; Thon, K.; Klotz, U. Telomere length in different tissues of elderly patients. Mech. Ageing Dev. 2000, 119, 89-99. [CrossRef]

112. Gardner, J.P.; Kimura, M.; Chai, W.; Durrani, J.F.; Tchakmakjian, L.; Cao, X.; Lu, X.; Li, G.; Peppas, A.P.; Skurnick, J.; et al. Telomere dynamics in macaques and humans. J. Gerontol. Ser. A 2007, 62, 367-374. [CrossRef]

113. Dlouha, D.; Maluskova, J.; Kralova Lesna, I.; Lanska, V.; Hubacek, J.A. Comparison of the relative telomere length measured in leukocytes and eleven different human tissues. Physiol. Res. 2014, 63 (Suppl. S3), S343-S350. [PubMed]

114. Takubo, K.; Izumiyama-Shimomura, N.; Honma, N.; Sawabe, M.; Arai, T.; Kato, M.; Oshimura, M.; Nakamura, K.-I. Telomere lengths are characteristic in each human individual. Exp. Gerontol. 2002, 37, 523-531. [CrossRef] 
115. Lin, J.; Epel, E.; Cheon, J.; Kroenke, C.; Sinclair, E.; Bigos, M.; Wolkowitz, O.; Mellon, S.; Blackburn, E. Analyses and comparisons of telomerase activity and telomere length in human T and B cells: Insights for epidemiology of telomere maintenance. J. Immunol. Methods 2010, 352, 71-80. [CrossRef] [PubMed]

116. Simpson, R.J. The effects of exercise on blood leukocyte numbers. In Exercise Immunology; Gleeson, M., Bishop, N., Walsh, N., Eds.; Taylor and Francis: Hoboken, NJ, USA, 2013; pp. 64-105.

117. Montpetit, A.J.; Alhareeri, A.A.; Montpetit, M.; Starkweather, A.R.; Elmore, L.W.; Filler, K.; Mohanraj, L.; Burton, C.W.; Menzies, V.S.; Lyon, D.E.; et al. Telomere length: A review of methods for measurement. Nurs. Res. 2014, 63, 289-299. [CrossRef] [PubMed]

118. Elbers, C.C.; Garcia, M.E.; Kimura, M.; Cummings, S.R.; Nalls, M.A.; Newman, A.B.; Park, V.; Sanders, J.L.; Tranah, G.J.; Tishkoff, S.A.; et al. Comparison between southern blots and qPCR analysis of leukocyte telomere length in the health ABC study. J. Gerontol. Ser. A 2014, 69, 527-531. [CrossRef] [PubMed]

119. Rufer, N.; Dragowska, W.; Thornbury, G.; Roosnek, E.; Lansdorp, P.M. Telomere length dynamics in human lymphocyte subpopulations measured by flow cytometry. Nat. Biotech. 1998, 16, 743-747. [CrossRef] [PubMed]

120. Parker, M.; Chen, X.; Bahrami, A.; Dalton, J.; Rusch, M.; Wu, G.; Easton, J.; Cheung, N.-K.; Dyer, M.; Mardis, E.R.; et al. Assessing telomeric DNA content in pediatric cancers using whole-genome sequencing data. Genome Biol. 2012, 13, R113. [CrossRef] [PubMed]

121. Treangen, T.J.; Salzberg, S.L. Repetitive DNA and next-generation sequencing: Computational challenges and solutions. Nat. Rev. Genet. 2011, 13, 36-46. [CrossRef] [PubMed]

122. Nersisyan, L.; Arakelyan, A. Computel: Computation of mean telomere length from whole-genome next-generation sequencing data. PLoS ONE 2015, 10, e0125201. [CrossRef] [PubMed]

123. Raschenberger, J.; Lamina, C.; Haun, M.; Kollerits, B.; Coassin, S.; Boes, E.; Kedenko, L.; Köttgen, A.; Kronenberg, F. Influence of DNA extraction methods on relative telomere length measurements and its impact on epidemiological studies. Sci. Rep. 2016, 6, 25398. [CrossRef] [PubMed]

124. Skvortsov, D.A.; Zvereva, M.E.; Shpanchenko, O.V.; Dontsova, O.A. Assays for detection of telomerase activity. Acta Nat. 2011, 3, 48-68.

125. Aviv, A.; Valdes, A.M.; Spector, T.D. Human telomere biology: Pitfalls of moving from the laboratory to epidemiology. Int. J. Epidemiol. 2006, 35, 1424-1429. [CrossRef] [PubMed]

126. Calado, R.T.; Young, N.S. Telomere diseases. N. Engl. J. Med. 2009, 361, 2353-2365. [CrossRef] [PubMed]

127. Prowse, K.R.; Greider, C.W. Developmental and tissue-specific regulation of mouse telomerase and telomere length. Proc. Natl. Acad. Sci. USA 1995, 92, 4818-4822. [CrossRef] [PubMed]

128. Kim, N.W.; Piatyszek, M.A.; Prowse, K.R.; Harley, C.B.; West, M.D.; Ho, P.L.; Coviello, G.M.; Wright, W.E.; Weinrich, S.L.; Shay, J.W. Specific association of human telomerase activity with immortal cells and cancer. Science 1994, 266, 2011-2015. [CrossRef] [PubMed]

129. Blasco, M.A.; Lee, H.-W.; Hande, M.P.; Samper, E.; Lansdorp, P.M.; DePinho, R.A.; Greider, C.W. Telomere shortening and tumor formation by mouse cells lacking telomerase rna. Cell 1997, 91, 25-34. [CrossRef]

130. Lee, H.-W.; Blasco, M.A.; Gottlieb, G.J.; Horner, J.W.; Greider, C.W.; DePinho, R.A. Essential role of mouse telomerase in highly proliferative organs. Nature 1998, 392, 569-574.

131. Ferrón, S.; Mira, H.; Franco, S.; Cano-Jaimez, M.; Bellmunt, E.; Ramírez, C.; Fariñas, I.; Blasco, M.A. Telomere shortening and chromosomal instability abrogates proliferation of adult but not embryonic neural stem cells. Development 2004, 131, 4059-4070. [CrossRef] [PubMed]

132. Franco, S.; Segura, I.; Riese, H.; Blasco, M. Telomere length is a key molecular determinant of angiogenic potential in vivo: Implications for cancer and aging. Cancer Res. 2002, 62, 552-559. [PubMed]

133. Hemann, M.T.; Rudolph, K.L.; Strong, M.A.; DePinho, R.A.; Chin, L.; Greider, C.W. Telomere dysfunction triggers developmentally regulated germ cell apoptosis. Mol. Biol. Cell 2001, 12, 2023-2030. [CrossRef] [PubMed]

134. Herrera, E.; Samper, E.; Martín-Caballero, J.; Flores, J.M.; Lee, H.W.; Blasco, M.A. Disease states associated with telomerase deficiency appear earlier in mice with short telomeres. EMBO J. 1999, 18, 2950-2960. [CrossRef] [PubMed]

135. Herrera, E.; Samper, E.; Blasco, M.A. Telomere shortening in $\mathrm{mTR}^{-/-}$embryos is associated with failure to close the neural tube. EMBO J. 1999, 18, 1172-1181. [CrossRef] [PubMed]

136. Herrera, E.; Martínez-A, C.; Blasco, M.A. Impaired germinal center reaction in mice with short telomeres. EMBO J. 2000, 19, 472-481. [CrossRef] [PubMed] 
137. Leri, A.; Franco, S.; Zacheo, A.; Barlucchi, L.; Chimenti, S.; Limana, F.; Nadal-Ginard, B.; Kajstura, J.; Anversa, P.; Blasco, M.A. Ablation of telomerase and telomere loss leads to cardiac dilatation and heart failure associated with p53 upregulation. EMBO J. 2003, 22, 131-139. [CrossRef] [PubMed]

138. Rudolph, K.L.; Chang, S.; Lee, H.-W.; Blasco, M.; Gottlieb, G.J.; Greider, C.; DePinho, R.A. Longevity, stress response and cancer in aging telomerase-deficient mice. Cell 1999, 96, 701-712. [CrossRef]

139. Samper, E.; Fernández, P.; Eguia, R.; Martin-Rivera, L.; Bernad, A.; Blasco, M.A.; Aracil, M. Long-term repopulating ability of telomerase-deficient murine hematopoietic stem cells. Blood 2002, 99, 2767-2775. [CrossRef] [PubMed]

140. Samper, E.; Flores, J.M.; Blasco, M.A. Restoration of telomerase activity rescues chromosomal instability and premature aging in Terc ${ }^{-/}$mice with short telomeres. EMBO Rep. 2001, 2, 800-807. [CrossRef] [PubMed]

141. Calado, R.T.; Dumitriu, B. Telomere dynamics in mice and humans. Semin. Hematol. 2013, 50, 165-174. [CrossRef] [PubMed]

142. Kishi, S.; Uchiyama, J.; Baughman, A.M.; Goto, T.; Lin, M.C.; Tsai, S.B. The zebrafish as a vertebrate model of functional aging and very gradual senescence. Exp. Gerontol. 2003, 38, 777-786. [CrossRef]

143. Pierce, A.J.; Johnson, R.D.; Thompson, L.H.; Jasin, M. XRCC3 promotes homology-directed repair of DNA damage in mammalian cells. Genes Dev. 1999, 13, 2633-2638. [CrossRef] [PubMed]

144. Lau, B.W.-M.; Wong, A.O.-L.; Tsao, G.S.-W.; So, K.-F.; Yip, H.K.-F. Molecular cloning and characterization of the zebrafish (Danio rerio) telomerase catalytic subunit (telomerase reverse transcriptase, TERT). J. Mol. Neurosci. 2008, 34, 63-75. [CrossRef] [PubMed]

145. Henriques, C.M.; Carneiro, M.C.; Tenente, I.M.; Jacinto, A.; Ferreira, M.G. Telomerase is required for zebrafish lifespan. PLoS Genet. 2013, 9, e1003214. [CrossRef] [PubMed]

146. Delany, M.E.; Krupkin, A.B.; Miller, M.M. Organization of telomere sequences in birds: Evidence for arrays of extreme length and for in vivo shortening. Cytogenet. Genome Res. 2000, 90, 139-145. [CrossRef] [PubMed]

147. Steinert, S.; White, D.M.; Zou, Y.; Shay, J.W.; Wright, W.E. Telomere biology and cellular aging in nonhuman primate cells. Exp. Cell Res. 2002, 272, 146-152. [CrossRef] [PubMed]

148. Fitzgerald, M.S.; Riha, K.; Gao, F.; Ren, S.; McKnight, T.D.; Shippen, D.E. Disruption of the telomerase catalytic subunit gene from arabidopsis inactivates telomerase and leads to a slow loss of telomeric DNA. Proc. Natl. Acad. Sci. USA 1999, 96, 14813-14818. [CrossRef] [PubMed]

149. Riha, K.; McKnight, T.D.; Griffing, L.R.; Shippen, D.E. Living with genome instability: Plant responses to telomere dysfunction. Science 2001, 291, 1797-1800. [CrossRef] [PubMed]

150. Meier, B.; Clejan, I.; Liu, Y.; Lowden, M.; Gartner, A.; Hodgkin, J.; Ahmed, S. Trt-1 is the caenorhabditis elegans catalytic subunit of telomerase. PLoS Genet. 2006, 2, e18. [CrossRef] [PubMed]

151. Raices, M.; Maruyama, H.; Dillin, A.; Karlseder, J. Uncoupling of longevity and telomere length in c. Elegans. PLoS Genet. 2005, 1, e30.

152. Walter, M.F.; Biessmann, M.R.; Benitez, C.; Török, T.; Mason, J.M.; Biessmann, H. Effects of telomere length in drosophila melanogaster on life span, fecundity and fertility. Chromosoma 2007, 116, 41-51. [CrossRef] [PubMed]

153. Fitzpatrick, A.L.; Kronmal, R.A.; Gardner, J.P.; Psaty, B.M.; Jenny, N.S.; Tracy, R.P.; Walston, J.; Kimura, M.; Aviv, A. Leukocyte telomere length and cardiovascular disease in the cardiovascular health study. Am. J. Epidemiol. 2007, 165, 14-21. [CrossRef] [PubMed]

154. Huzen, J.; de Boer, R.A.; van Veldhuisen, D.J.; van Gilst, W.H.; van der Harst, P. The emerging role of telomere biology in cardiovascular disease. Front. Biosci. 2010, 15, 35-45. [CrossRef]

155. Willeit, P.; Willeit, J.; Mayr, A.; Weger, S.; Oberhollenzer, F.; Brandstätter, A.; Kronenberg, F.; Kiechl, S. Telomere length and risk of incident cancer and cancer mortality. JAMA 2010, 304, 69-75. [CrossRef] [PubMed]

156. Zhang, W.; Chen, Y.; Wang, Y.; Liu, P.; Zhang, M.; Zhang, C.; Hu, F.B.; Hui, R. Short telomere length in blood leucocytes contributes to the presence of atherothrombotic stroke and haemorrhagic stroke and risk of post-stroke death. Clin. Sci. 2013, 125, 27-43. [CrossRef] [PubMed]

157. Salpea, K.D.; Talmud, P.J.; Cooper, J.A.; Maubaret, C.G.; Stephens, J.W.; Abelak, K.; Humphries, S.E. Association of telomere length with type 2 diabetes, oxidative stress and UCP2 gene variation. Atherosclerosis 2010, 209, 42-50. [CrossRef] [PubMed]

158. Sampson, M.J.; Winterbone, M.S.; Hughes, J.C.; Dozio, N.; Hughes, D.A. Monocyte telomere shortening and oxidative DNA damage in type 2 diabetes. Diabetes Care 2006, 29, 283-289. [CrossRef] [PubMed] 
159. Zee, R.Y.L.; Castonguay, A.J.; Barton, N.S.; Germer, S.; Martin, M. Mean leukocyte telomere length shortening and type 2 diabetes mellitus: A case-control study. Transl. Res. 2010, 155, 166-169. [CrossRef] [PubMed]

160. Honig, L.S.; Kang, M.; Schupf, N.; Lee, J.H.; Mayeux, R. Association of shorter leukocyte telomere repeat length with dementia and mortality. Arch. Neurol. 2012, 69, 1332-1339. [CrossRef] [PubMed]

161. Jenkins, E.C.; Velinov, M.T.; Ye, L.; Gu, H.; Li, S.; Jenkins, E.C.; Brooks, S.S.; Pang, D.; Devenny, D.A.; Zigman, W.B.; et al. Telomere shortening in T lymphocytes of older individuals with down syndrome and dementia. Neurobiol. Aging 2006, 27, 941-945. [CrossRef] [PubMed]

162. Martin-Ruiz, C.; Dickinson, H.O.; Keys, B.; Rowan, E.; Kenny, R.A.; von Zglinicki, T. Telomere length predicts poststroke mortality, dementia and cognitive decline. Ann. Neurol. 2006, 60, 174-180. [CrossRef] [PubMed]

163. Rode, L.; Bojesen, S.E.; Weischer, M.; Vestbo, J.; Nordestgaard, B.G. Short telomere length, lung function and chronic obstructive pulmonary disease in 46,396 individuals. Thorax 2013, 68, 429-435. [CrossRef] [PubMed]

164. Buckingham, E.M.; Klingelhutz, A.J. The role of telomeres in the ageing of human skin. Exp. Dermatol. 2011, 20, 297-302. [CrossRef] [PubMed]

165. Samani, N.J.; Boultby, R.; Butler, R.; Thompson, J.R.; Goodall, A.H. Telomere shortening in atherosclerosis. Lancet 2001, 358, 472-473. [CrossRef]

166. Brouilette, S.; Singh, R.K.; Thompson, J.R.; Goodall, A.H.; Samani, N.J. White cell telomere length and risk of premature myocardial infarction. Arterioscler. Thromb. Vasc. Biol. 2003, 23, 842-846. [CrossRef] [PubMed]

167. Brouilette, S.W.; Whittaker, A.; Stevens, S.E.; van der Harst, P.; Goodall, A.H.; Samani, N.J. Telomere length is shorter in healthy offspring of subjects with coronary artery disease: Support for the telomere hypothesis. Heart 2008, 94, 422-425. [CrossRef] [PubMed]

168. Carty, C.L.; Kooperberg, C.; Liu, J.; Herndon, M.; Assimes, T.; Hou, L.; Kroenke, C.H.; LaCroix, A.Z.; Kimura, M.; Aviv, A.; et al. Leukocyte telomere length and risks of incident coronary heart disease and mortality in a racially diverse population of postmenopausal women. Arterioscler. Thromb. Vasc. Biol. 2015, 35, 2225-2231. [CrossRef] [PubMed]

169. D’Mello, M.J.J.; Ross, S.A.; Briel, M.; Anand, S.S.; Gerstein, H.; Paré, G. Association between shortened leukocyte telomere length and cardiometabolic outcomes: Systematic review and meta-analysis. Circ. Cardiovasc. Genet. 2015, 8, 82-90. [CrossRef] [PubMed]

170. Ellehoj, H.; Bendix, L.; Osler, M. Leucocyte telomere length and risk of cardiovascular disease in a cohort of 1397 danish men and women. Cardiology 2016, 133, 173-177. [CrossRef] [PubMed]

171. Haycock, P.C.; Heydon, E.E.; Kaptoge, S.; Butterworth, A.S.; Thompson, A.; Willeit, P. Leucocyte telomere length and risk of cardiovascular disease: Systematic review and meta-analysis. BMJ 2014, 349, g4227. [CrossRef] [PubMed]

172. Matthews, C.; Gorenne, I.; Scott, S.; Figg, N.; Kirkpatrick, P.; Ritchie, A.; Goddard, M.; Bennett, M. Vascular smooth muscle cells undergo telomere-based senescence in human atherosclerosis: Effects of telomerase and oxidative stress. Circ. Res. 2006, 99, 156-164. [CrossRef] [PubMed]

173. Willeit, P.; Willeit, J.; Brandstätter, A.; Ehrlenbach, S.; Mayr, A.; Gasperi, A.; Weger, S.; Oberhollenzer, F.; Reindl, M.; Kronenberg, F.; et al. Cellular aging reflected by leukocyte telomere length predicts advanced atherosclerosis and cardiovascular disease risk. Arterioscler. Thromb. Vasc. Biol. 2010, 30, 1649-1656. [CrossRef] [PubMed]

174. Toupance, S.; Labat, C.; Temmar, M.; Rossignol, P.; Kimura, M.; Aviv, A.; Benetos, A. Short telomeres but not telomere attrition rates, are associated with carotid atherosclerosis. Hypertension 2017, 70, 420-425. [CrossRef] [PubMed]

175. Strandberg, T.E.; Saijonmaa, O.; Tilvis, R.S.; Pitkälä, K.H.; Strandberg, A.Y.; Salomaa, V.; Miettinen, T.A.; Fyhrquist, F. Telomere length in old age and cholesterol across the life course. J. Am. Geriatr. Soc. 2011, 59, 1979-1981. [CrossRef] [PubMed]

176. Benetos, A.; Okuda, K.; Lajemi, M.; Kimura, M.; Thomas, F.; Skurnick, J.; Labat, C.; Bean, K.; Aviv, A. Telomere length as an indicator of biological aging: The gender effect and relation with pulse pressure and pulse wave velocity. Hypertension 2001, 37, 381-385. [CrossRef] [PubMed]

177. Müezzinler, A.; Zaineddin, A.K.; Brenner, H. Body mass index and leukocyte telomere length in adults: A systematic review and meta-analysis. Obes. Rev. 2014, 15, 192-201. [CrossRef] [PubMed]

178. Strandberg, T.E.; Strandberg, A.Y.; Saijonmaa, O.; Tilvis, R.S.; Pitkälä, K.H.; Fyhrquist, F. Association between alcohol consumption in healthy midlife and telomere length in older men. The helsinki businessmen study. Eur. J. Epidemiol. 2012, 27, 815-822. [CrossRef] [PubMed] 
179. Cherkas, L.F.; Aviv, A.; Valdes, A.M.; Hunkin, J.L.; Gardner, J.P.; Surdulescu, G.L.; Kimura, M.; Spector, T.D. The effects of social status on biological aging as measured by white-blood-cell telomere length. Aging Cell 2006, 5, 361-365. [CrossRef] [PubMed]

180. Bischoff, C.; Petersen, H.C.; Graakjaer, J.; Andersen-Ranberg, K.; Vaupel, J.W.; Bohr, V.A.; Kolvraa, S.; Christensen, K. No association between telomere length and survival among the elderly and oldest old. Epidemiology 2006, 17, 190-194. [CrossRef] [PubMed]

181. Neuner, B.; Lenfers, A.; Kelsch, R.; Jäger, K.; Brüggmann, N.; van der Harst, P.; Walter, M. Telomere length is not related to established cardiovascular risk factors but does correlate with red and white blood cell counts in a german blood donor population. PLoS ONE 2015, 10, e0139308. [CrossRef] [PubMed]

182. De Meyer, T.; Rietzschel, E.R.; de Buyzere, M.L.; Langlois, M.R.; de Bacquer, D.; Segers, P.; van Damme, P.; de Backer, G.G.; van Oostveldt, P.; van Criekinge, W.; et al. Systemic telomere length and preclinical atherosclerosis: The asklepios study. Eur. Heart J. 2009, 30, 3074-3081. [CrossRef] [PubMed]

183. Fernández-Alvira, J.M.; Fuster, V.; Dorado, B.; Soberón, N.; Flores, I.; Gallardo, M.; Pocock, S.; Blasco, M.A.; Andrés, V. Short telomere load, telomere length and subclinical atherosclerosis: The pesa study. J. Am. Coll. Cardiol. 2016, 67, 2467-2476. [CrossRef] [PubMed]

184. Østhus, I.B.Ø.; Lydersen, S.; Dalen, H.; Nauman, J.; Wisløff, U. Association of telomere length with myocardial infarction: A prospective cohort from the population based HUNT 2 study. Prog. Cardiovasc. Dis. 2017, 59, 649-655. [CrossRef] [PubMed]

185. Codd, V.; Nelson, C.P.; Albrecht, E.; Mangino, M.; Deelen, J.; Buxton, J.L.; Hottenga, J.J.; Fischer, K.; Esko, T.; Surakka, I.; et al. Identification of seven loci affecting mean telomere length and their association with disease. Nat. Genet. 2013, 45. [CrossRef] [PubMed]

186. Haycock, P.C. Association between telomere length and risk of cancer and non-neoplastic diseases: A mendelian randomization study. JAMA Oncol. 2017, 3, 636-651. [PubMed]

187. Madrid, A.S.; Rode, L.; Nordestgaard, B.G.; Bojesen, S.E. Short telomere length and ischemic heart disease: Observational and genetic studies in 290,022 individuals. Clin. Chem. 2016, 62, 1140-1149. [CrossRef] [PubMed]

188. Strazhesko, I.D.; Tkacheva, O.N.; Akasheva, D.U.; Dudinskaya, E.N.; Plokhova, E.V.; Pykhtina, V.S.; Kruglikova, A.S.; Kokshagina, N.V.; Sharashkina, N.V.; Agaltsov, M.V.; et al. Atorvastatin therapy modulates telomerase activity in patients free of atherosclerotic cardiovascular diseases. Front. Pharmacol. 2016, 7, 347. [CrossRef] [PubMed]

189. Bode-Böger, S.M.; Martens-Lobenhoffer, J.; Täger, M.; Schröder, H.; Scalera, F. Aspirin reduces endothelial cell senescence. Biochem. Biophys. Res. Commun. 2005, 334, 1226-1232. [CrossRef] [PubMed]

190. Li, F.; Guo, Y.I.; Jiang, X.I.N.; Zhong, J.; Li, G.; Sun, S. Aspirin inhibits human telomerase activation in unstable carotid plaques. Exp. Ther. Med. 2013, 6, 204-208. [CrossRef] [PubMed]

191. Donnini, S.; Terzuoli, E.; Ziche, M.; Morbidelli, L. Sulfhydryl angiotensin-converting enzyme inhibitor promotes endothelial cell survival through nitric-oxide synthase, fibroblast growth factor-2 and telomerase cross-talk. J. Pharmacol. Exp. Ther. 2010, 332, 776-784. [PubMed]

192. Townsley, D.M.; Dumitriu, B.; Liu, D.; Biancotto, A.; Weinstein, B.; Chen, C.; Hardy, N.; Mihalek, A.D.; Lingala, S.; Kim, Y.J.; et al. Danazol treatment for telomere diseases. N. Engl. J. Med. 2016, 374, 1922-1931. [CrossRef] [PubMed]

193. Artandi, S.E.; DePinho, R.A. Telomeres and telomerase in cancer. Carcinogenesis 2010, 31, 9-18. [CrossRef] [PubMed]

194. Anic, G.M.; Sondak, V.K.; Messina, J.L.; Fenske, N.A.; Zager, J.S.; Cherpelis, B.S.; Lee, J.-H.; Fulp, W.J.; Epling-Burnette, P.K.; Park, J.Y.; et al. Telomere length and risk of melanoma, squamous cell carcinoma and basal cell carcinoma. Cancer Epidemiol. 2013, 37, 434-439. [CrossRef] [PubMed]

195. Iles, M.M.; Bishop, D.T.; Taylor, J.C.; Hayward, N.K.; Brossard, M.; Cust, A.E.; Dunning, A.M.; Lee, J.E.; Moses, E.K.; Akslen, L.A.; et al. The effect on melanoma risk of genes previously associated with telomere length. J. Natl. Cancer Inst. 2014, 106, dju267. [CrossRef] [PubMed]

196. Julin, B.; Shui, I.; Heaphy, C.M.; Joshu, C.E.; Meeker, A.K.; Giovannucci, E.; De Vivo, I.; Platz, E.A. Circulating leukocyte telomere length and risk of overall and aggressive prostate cancer. Br. J. Cancer 2015, 112, 769-776. [CrossRef] [PubMed] 
197. Lynch, S.M.; Major, J.M.; Cawthon, R.; Weinstein, S.J.; Virtamo, J.; Lan, Q.; Rothman, N.; Albanes, D.; Stolzenberg-Solomon, R.Z. A prospective analysis of telomere length and pancreatic cancer in the alpha-tocopherol beta-carotene cancer (ATBC) prevention study. Int. J. Cancer 2013, 133, 2672-2680. [CrossRef] [PubMed]

198. Machiela, M.J.; Hsiung, C.A.; Shu, X.-O.; Seow, W.J.; Wang, Z.; Matsuo, K.; Hong, Y.-C.; Seow, A.; Wu, C.; Hosgood, H.D.; et al. Genetic variants associated with longer telomere length are associated with increased lung cancer risk among never-smoking women in asia: A report from the female lung cancer consortium in asia. Int. J. Cancer 2015, 137, 311-319. [CrossRef] [PubMed]

199. Nan, H.; Du, M.; de Vivo, I.; Manson, J.E.; Liu, S.; McTiernan, A.; Curb, J.D.; Lessin, L.S.; Bonner, M.R.; Guo, Q.; et al. Shorter telomeres associate with a reduced risk of melanoma development. Cancer Res. 2011, 71, 6758-6763. [CrossRef] [PubMed]

200. Pellatt, A.J.; Wolff, R.K.; Torres-Mejia, G.; John, E.M.; Herrick, J.S.; Lundgreen, A.; Baumgartner, K.B.; Giuliano, A.R.; Hines, L.M.; Fejerman, L.; et al. Telomere length, telomere-related genes and breast cancer risk: The breast cancer health disparities study. Genes Chromosom. Cancer 2013, 52, 595-609. [CrossRef] [PubMed]

201. Qu, S.; Wen, W.; Shu, X.-O.; Chow, W.-H.; Xiang, Y.-B.; Wu, J.; Ji, B.-T.; Rothman, N.; Yang, G.; Cai, Q.; et al. Association of leukocyte telomere length with breast cancer risk: Nested case-control findings from the shanghai women's health study. Am. J. Epidemiol. 2013, 177, 617-624. [CrossRef] [PubMed]

202. Sanchez-Espiridion, B.; Chen, M.; Chang, J.Y.; Lu, C.; Chang, D.W.; Roth, J.A.; Wu, X.; Gu, J. Telomere length in peripheral blood leukocytes and lung cancer risk: A large case-control study in caucasians. Cancer Res. 2014, 74, 2476-2486. [CrossRef] [PubMed]

203. Seow, W.J.; Cawthon, R.M.; Purdue, M.P.; Hu, W.; Gao, Y.-T.; Huang, W.-Y.; Weinstein, S.J.; Ji, B.-T.; Virtamo, J.; Hosgood, H.D.; et al. Telomere length in white blood cell DNA and lung cancer: A pooled analysis of three prospective cohorts. Cancer Res. 2014, 74, 4090-4098. [CrossRef] [PubMed]

204. Shay, J.W.; Bacchetti, S. A survey of telomerase activity in human cancer. Eur. J. Cancer. 1997, 33, 787-791. [CrossRef]

205. Novak, K.D. Telomeres and telomerases in cancer. Medscape Gen. Med. 2003, 5, 21.

206. Williams, G.C. Pleiotropy, natural selection and the evolution of senescence. Evolution 1957, 11, $398-411$. [CrossRef]

207. Wang, S.; Chen, Y.; Qu, F.; He, S.; Huang, X.; Jiang, H.; Jin, T.; Wan, S.; Xing, J. Association between leukocyte telomere length and glioma risk: A case-control study. Neuro-Oncol. 2014, 16, 505-512. [CrossRef] [PubMed]

208. Wu, X.; Amos, C.I.; Zhu, Y.; Zhao, H.; Grossman, B.H.; Shay, J.W.; Luo, S.; Hong, W.K.; Spitz, M.R. Telomere dysfunction: A potential cancer predisposition factor. J. Natl. Cancer Inst. 2003, 95, 1211-1218. [CrossRef] [PubMed]

209. Cesare, A.J.; Reddel, R.R. Alternative lengthening of telomeres: Models, mechanisms and implications. Nat. Rev. Genet. 2010, 11, 319-330. [CrossRef] [PubMed]

210. Yang, T.-L.B.; Song, S.; Johnson, F.B. Chapter 7-Contributions of telomere biology to human age-related disease. In Handbook of the Biology of Aging, 8th ed.; Academic Press: San Diego, CA, USA, 2016; pp. 205-239.

211. Cawthon, R.M.; Smith, K.R.; O’Brien, E.; Sivatchenko, A.; Kerber, R.A. Association between telomere length in blood and mortality in people aged 60 years or older. Lancet 2003, 361,393-395. [CrossRef]

212. Deelen, J.; Beekman, M.; Codd, V.; Trompet, S.; Broer, L.; Hägg, S.; Fischer, K.; Thijssen, P.E.; Suchiman, H.E.D.; Postmus, I.; et al. Leukocyte telomere length associates with prospective mortality independent of immune-related parameters and known genetic markers. Int. J. Epidemiol. 2014, 3, 878-886. [CrossRef] [PubMed]

213. Njajou, O.T.; Cawthon, R.M.; Damcott, C.M.; Wu, S.H.; Ott, S.; Garant, M.J.; Blackburn, E.H.; Mitchell, B.D.; Shuldiner, A.R.; Hsueh, W.C. Telomere length is paternally inherited and is associated with parental lifespan. Proc. Natl. Acad. Sci. USA 2007, 104, 12135-12139. [CrossRef] [PubMed]

214. Soerensen, M.; Thinggaard, M.; Nygaard, M.; Dato, S.; Tan, Q.; Hjelmborg, J.; Andersen-Ranberg, K.; Stevnsner, T.; Bohr, V.A.; Kimura, M.; et al. Genetic variation in tert and terc and human leukocyte telomere length and longevity: A cross-sectional and longitudinal analysis. Aging Cell 2012, 11, 223-227. [CrossRef] [PubMed] 
215. Njajou, O.T.; Hsueh, W.-C.; Blackburn, E.H.; Newman, A.B.; Wu, S.-H.; Li, R.; Simonsick, E.M.; Harris, T.M.; Cummings, S.R.; Cawthon, R.M.; et al. Association between telomere length, specific causes of death and years of healthy life in health, aging and body composition, a population-based cohort study. J. Gerontol. Ser. A Biol. Sci. Med. Sci. 2009, 64, 860-864. [CrossRef] [PubMed]

216. Svensson, J.; Karlsson, M.K.; Ljunggren, Ö.; Tivesten, Å.; Mellström, D.; Movérare-Skrtic, S. Leukocyte telomere length is not associated with mortality in older men. Exp. Gerontol. 2014, 57, 6-12. [CrossRef] [PubMed]

217. Gardner, M.; Bann, D.; Wiley, L.; Cooper, R.; Hardy, R.; Nitsch, D.; Martin-Ruiz, C.; Shiels, P.; Sayer, A.A.; Barbieri, M.; et al. Gender and telomere length: Systematic review and meta-analysis. Exp. Gerontol. 2014, 51, 15-27. [CrossRef] [PubMed]

218. Christensen, K.; Thinggaard, M.; McGue, M.; Rexbye, H.; Hjelmborg, J.V.; Aviv, A.; Gunn, D.; van der Ouderaa, F.; Vaupel, J.W. Perceived age as clinically useful biomarker of ageing: Cohort study. BMJ 2009, 339, b5262. [CrossRef] [PubMed]

219. Astrup, A.S.; Tarnow, L.; Jorsal, A.; Lajer, M.; Nzietchueng, R.; Benetos, A.; Rossing, P.; Parving, H.-H. Telomere length predicts all-cause mortality in patients with type 1 diabetes. Diabetologia 2009, 53, 45-48. [CrossRef] [PubMed]

220. Bakaysa, S.L.; Mucci, L.A.; Slagboom, P.E.; Boomsma, D.I.; McClearn, G.E.; Johansson, B.; Pedersen, N.L. Telomere length predicts survival independent of genetic influences. Aging Cell 2007, 6, 769-774. [CrossRef] [PubMed]

221. Fitzpatrick, A.L.; Kronmal, R.A.; Kimura, M.; Gardner, J.P.; Psaty, B.M.; Jenny, N.S.; Tracy, R.P.; Hardikar, S.; Aviv, A. Leukocyte telomere length and mortality in the cardiovascular health study. J. Gerontol. Ser. A Biol. Sci. Med. Sci. 2011, 66, 421-429. [CrossRef] [PubMed]

222. Glei, D.A.; Goldman, N.; Weinstein, M.; Risques, R.A. Shorter ends, faster end? Leukocyte telomere length and mortality among older taiwanese. J. Gerontol. Ser. A Biol. Sci. Med. Sci. 2014, 70, 1490-1498. [CrossRef] [PubMed]

223. Kim, J.H.; Ko, J.H.; Lee, D.C.; Lim, I.; Bang, H. Habitual physical exercise has beneficial effects on telomere length in postmenopausal women. Menopause 2012, 19, 1109-1115. [CrossRef] [PubMed]

224. Lee, J.; Sandford, A.J.; Connett, J.E.; Yan, J.; Mui, T.; Li, Y.; Daley, D.; Anthonisen, N.R.; Brooks-Wilson, A.; Man, S.F.P.; et al. The relationship between telomere length and mortality in chronic obstructive pulmonary disease (COPD). PLoS ONE 2012, 7, e35567. [CrossRef] [PubMed]

225. Rehkopf, D.H.; Dow, W.H.; Rosero-Bixby, L.; Lin, J.; Epel, E.S.; Blackburn, E.H. Longer leukocyte telomere length in Costa Rica's nicoyan peninsula: A population-based study. Exp. Gerontol. 2013, 48, 1266-1273. [CrossRef] [PubMed]

226. Strandberg, T.E.; Saijonmaa, O.; Tilvis, R.S.; Pitkälä, K.H.; Strandberg, A.Y.; Miettinen, T.A.; Fyhrquist, F. Association of telomere length in older men with mortality and midlife body mass index and smoking. J. Gerontol. Ser. A Biol. Sci. Med. Sci. 2011, 66, 815-820. [CrossRef] [PubMed]

227. Weischer, M.; Bojesen, S.E.; Cawthon, R.M.; Freiberg, J.J.; Tybjærg-Hansen, A.; Nordestgaard, B.G. Short telomere length, myocardial infarction, ischemic heart disease and early death. Arterioscler. Thromb. Vasc. Biol. 2012, 32, 822-829. [CrossRef] [PubMed]

228. Arai, Y.; Martin-Ruiz, C.M.; Takayama, M.; Abe, Y.; Takebayashi, T.; Koyasu, S.; Suematsu, M.; Hirose, N.; von Zglinicki, T. Inflammation but not telomere length, predicts successful ageing at extreme old age: A longitudinal study of semi-supercentenarians. EBioMedicine 2015, 2, 1549-1558. [CrossRef] [PubMed]

229. Bendix, L.; Thinggaard, M.; Fenger, M.; Kolvraa, S.; Avlund, K.; Linneberg, A.; Osler, M. Longitudinal changes in leukocyte telomere length and mortality in humans. J. Gerontol. Ser. A 2014, 69, 231-239. [CrossRef] [PubMed]

230. Kimura, M.; Hjelmborg, J.V.; Gardner, J.P.; Bathum, L.; Brimacombe, M.; Lu, X.; Christiansen, L.; Vaupel, J.W.; Aviv, A.; Christensen, K. Telomere length and mortality: A study of leukocytes in elderly danish twins. Am. J. Epidemiol. 2008, 167, 799-806. [CrossRef] [PubMed]

231. Glei, D.A.; Goldman, N.; Risques, R.A.; Rehkopf, D.H.; Dow, W.H.; Rosero-Bixby, L.; Weinstein, M. Predicting survival from telomere length versus conventional predictors: A multinational population-based cohort study. PLoS ONE 2016, 11, e0152486. [CrossRef] [PubMed]

232. Heidinger, B.J.; Blount, J.D.; Boner, W.; Griffiths, K.; Metcalfe, N.B.; Monaghan, P. Telomere length in early life predicts lifespan. Proc. Natl. Acad. Sci. USA 2012, 109, 1743-1748. [CrossRef] [PubMed] 
233. Bendix, L.; Gade, M.M.; Staun, P.W.; Kimura, M.; Jeune, B.; Hjelmborg, J.V.; Aviv, A.; Christensen, K. Leukocyte telomere length and physical ability among danish twins age 70+. Mech. Ageing Dev. 2011, 132, 568-572. [CrossRef] [PubMed]

234. Denham, J.; Nelson, C.P.; O’Brien, B.J.; Nankervis, S.A.; Denniff, M.; Harvey, J.T.; Marques, F.Z.; Codd, V.; Zukowska-Szczechowska, E.; Samani, N.J. Longer leukocyte telomeres are associated with ultra-endurance exercise independent of cardiovascular risk factors. PLoS ONE 2013, 8, e69377. [CrossRef] [PubMed]

235. Du, M.; Prescott, J.; Kraft, P.; Han, J.; Giovannucci, E.; Hankinson, S.E.; De Vivo, I. Physical activity, sedentary behavior and leukocyte telomere length in women. Am. J. Epidemiol. 2012, 175, 414-422. [CrossRef] [PubMed]

236. Garland, S.N.; Johnson, B.; Palmer, C.; Speck, R.M.; Donelson, M.; Xie, S.X.; DeMichele, A.; Mao, J.J. Physical activity and telomere length in early stage breast cancer survivors. Breast Cancer Res. 2014, 16, 1-9. [CrossRef] [PubMed]

237. Kingma, E.M.; de Jonge, P.; van der Harst, P.; Ormel, J.; Rosmalen, J.G.M. The association between intelligence and telomere length: A longitudinal population based study. PLoS ONE 2012, 7, e49356. [CrossRef] [PubMed]

238. Krauss, J.; Farzaneh-Far, R.; Puterman, E.; Na, B.; Lin, J.; Epel, E.; Blackburn, E.; Whooley, M.A. Physical fitness and telomere length in patients with coronary heart disease: Findings from the heart and soul study. PLOS ONE 2011, 6, e26983. [CrossRef] [PubMed]

239. LaRocca, T.J.; Seals, D.R.; Pierce, G.L. Leukocyte telomere length is preserved with aging in endurance exercise-trained adults and related to maximal aerobic capacity. Mech. Ageing Dev. 2010, 131, 165-167. [CrossRef] [PubMed]

240. Loprinzi, P.D. Cardiorespiratory capacity and leukocyte telomere length among adults in the united states. Am. J. Epidemiol. 2015, 182, 198-201. [CrossRef] [PubMed]

241. Ludlow, A.T.; Zimmerman, J.B.; Witkowski, S.; Hearn, J.W.; Hatfield, B.D.; Roth, S.M. Relationship between physical activity level, telomere length and telomerase activity. Med. Sci. Sports Exerc. 2008, 40, 1764-1771. [CrossRef] [PubMed]

242. Østhus, I.B.Ø.; Sgura, A.; Berardinelli, F.; Alsnes, I.V.; Brønstad, E.; Rehn, T.; Støbakk, P.K.; Hatle, H.; Wisløff, U.; Nauman, J. Telomere length and long-term endurance exercise: Does exercise training affect biological age? A pilot study. PLoS ONE 2012, 7, e52769. [CrossRef] [PubMed]

243. Puterman, E.; Lin, J.; Krauss, J.; Blackburn, E.H.; Epel, E.S. Determinants of telomere attrition over 1 year in healthy older women: Stress and health behaviors matter. Mol. Psychiatry 2015, 20, 529-535. [CrossRef] [PubMed]

244. Savela, S.; Saijonmaa, O.; Strandberg, T.E.; Koistinen, P.; Strandberg, A.Y.; Tilvis, R.S.; Pitkälä, K.H.; Miettinen, T.A.; Fyhrquist, F. Physical activity in midlife and telomere length measured in old age. Exp. Gerontol. 2012, 48, 81-84. [CrossRef] [PubMed]

245. Silva, L.C.R.; de Araújo, A.L.; Fernandes, J.R.; Matias, M.S.; Silva, P.R.; Duarte, A.J.S.; Garcez Leme, L.E.; Benard, G. Moderate and intense exercise lifestyles attenuate the effects of aging on telomere length and the survival and composition of T cell subpopulations. AGE 2016, 38, 1-16. [CrossRef] [PubMed]

246. Venturelli, M.; Morgan, G.R.; Donato, A.J.; Reese, V.; Bottura, R.; Tarperi, C.; Milanese, C.; Schena, F.; Reggiani, C.; Naro, F.; et al. Cellular aging of skeletal muscle: Telomeric and free radical evidence that physical inactivity is responsible and not age. Clin. Sci. 2014, 127, 415-421. [CrossRef] [PubMed]

247. Werner, C.; Furster, T.; Widmann, T.; Poss, J.; Roggia, C.; Hanhoun, M.; Scharhag, J.; Buchner, N.; Meyer, T.; Kindermann, W.; et al. Physical exercise prevents cellular senescence in circulating leukocytes and in the vessel wall. Circulation 2009, 120, 2438-2447. [CrossRef] [PubMed]

248. Zhu, H.; Wang, X.; Gutin, B.; Davis, C.L.; Keeton, D.; Thomas, J.; Stallmann-Jorgensen, I.; Mooken, G.; Bundy, V.; Snieder, H.; et al. Leukocyte telomere length in healthy caucasian and african-american adolescents: Relationships with race, sex, adiposity, adipokines and physical activity. J. Pediatr. 2011, 158, 215-220. [CrossRef] [PubMed]

249. Loprinzi, P.D.; Sng, E. Mode-specific physical activity and leukocyte telomere length among U.S. Adults: Implications of running on cellular aging. Prev. Med. 2016, 85, 17-19. [CrossRef] [PubMed]

250. Mathur, S.; Ardestani, A.; Parker, B.; Cappizzi, J.; Polk, D.; Thompson, P.D. Telomere length and cardiorespiratory fitness in marathon runners. J. Investig. Med. 2013, 61, 613-615. [CrossRef] [PubMed]

251. Rae, D.E.; Vignaud, A.; Butler-Browne, G.S.; Thornell, L.E.; Sinclair-Smith, C.; Derman, E.W.; Lambert, M.I.; Collins, M. Skeletal muscle telomere length in healthy, experienced, endurance runners. Eur. J. Appl. Physiol. 2010, 109, 323-330. [CrossRef] [PubMed] 
252. Mason, C.; Risques, R.-A.; Xiao, L.; Duggan, C.R.; Imayama, I.; Campbell, K.L.; Kong, A.; Foster-Schubert, K.E.; Wang, C.Y.; Alfano, C.M.; et al. Independent and combined effects of dietary weight loss and exercise on leukocyte telomere length in postmenopausal women. Obesity 2013, 21, E549-E554. [CrossRef] [PubMed]

253. Cassidy, A.; De Vivo, I.; Liu, Y.; Han, J.; Prescott, J.; Hunter, D.J.; Rimm, E.B. Associations between diet, lifestyle factors and telomere length in women. Am. J. Clin. Nutr. 2010, 91, 1273-1280. [CrossRef] [PubMed]

254. Denham, J.; O’Brien, B.J.; Prestes, P.R.; Brown, N.J.; Charchar, F.J. Increased expression of telomere-regulating genes in endurance athletes with long leukocyte telomeres. J. Appl. Physiol. 2016, 120, 148-158. [CrossRef] [PubMed]

255. Fujishiro, K.; Diez-Roux, A.V.; Landsbergis, P.A.; Jenny, N.S.; Seeman, T. Current employment status, occupational category, occupational hazard exposure and job stress in relation to telomere length: The multiethnic study of atherosclerosis (MESA). Occup. Environ. Med. 2013, 70, 552-560. [CrossRef] [PubMed]

256. Garcia-Calzon, S.; Gea, A.; Razquin, C.; Corella, D.; Lamuela-Raventos, R.M.; Martinez, J.A.; Martinez-Gonzalez, M.A.; Zalba, G.; Marti, A. Longitudinal association of telomere length and obesity indices in an intervention study with a mediterranean diet: The predimed-navarra trial. Int. J. Obes. (2005) 2014, 38, 177-182. [CrossRef] [PubMed]

257. Hovatta, I.; de Mello, V.D.F.; Kananen, L.; Lindström, J.; Eriksson, J.G.; Ilanne-Parikka, P.; Keinänen-Kiukaanniemi, S.; Peltonen, M.; Tuomilehto, J.; Uusitupa, M. Leukocyte telomere length in the finnish diabetes prevention study. PLoS ONE 2012, 7, e34948. [CrossRef] [PubMed]

258. Kadi, F.; Ponsot, E.; Piehl-Aulin, K.; Mackey, A.; Kjaer, M.; Oskarsson, E.; Holm, L. The effects of regular strength training on telomere length in human skeletal muscle. Med. Sci. Sports Exerc. 2008, 40, 82-87. [CrossRef] [PubMed]

259. Laine, M.K.; Eriksson, J.G.; Kujala, U.M.; Raj, R.; Kaprio, J.; Bäckmand, H.M.; Peltonen, M.; Sarna, S. Effect of intensive exercise in early adult life on telomere length in later life in men. J. Sports Sci. Med. 2015, 14, 239-245. [PubMed]

260. Laye, M.J.; Solomon, T.P.J.; Karstoft, K.; Pedersen, K.K.; Nielsen, S.D.; Pedersen, B.K. Increased shelterin mrna expression in peripheral blood mononuclear cells and skeletal muscle following an ultra-long-distance running event. J. Appl. Physiol. 2012, 112, 773-781. [CrossRef] [PubMed]

261. Ponsot, E.; Lexell, J.; Kadi, F. Skeletal muscle telomere length is not impaired in healthy physically active old women and men. Muscle Nerve 2008, 37, 467-472. [CrossRef] [PubMed]

262. Shin, Y.A.; Lee, J.H.; Song, W.; Jun, T.W. Exercise training improves the antioxidant enzyme activity with no changes of telomere length. Mech. Ageing Dev. 2008, 129, 254-260. [CrossRef] [PubMed]

263. Song, Z.; von Figura, G.; Liu, Y.; Kraus, J.M.; Torrice, C.; Dillon, P.; Rudolph-Watabe, M.; Ju, Z.; Kestler, H.A.; Sanoff, H.; et al. Lifestyle impacts on the aging-associated expression of biomarkers of DNA damage and telomere dysfunction in human blood. Aging Cell 2010, 9, 607-615. [CrossRef] [PubMed]

264. Sun, Q.; Shi, L.; Prescott, J.; Chiuve, S.E.; Hu, F.B.; De Vivo, I.; Stampfer, M.J.; Franks, P.W.; Manson, J.E.; Rexrode, K.M. Healthy lifestyle and leukocyte telomere length in U.S. Women. PLoS ONE 2012, 7, e38374. [CrossRef] [PubMed]

265. Tiainen, A.M.K.; Männistö, S.; Blomstedt, P.A.; Moltchanova, E.; Perälä, M.M.; Kaartinen, N.E.; Kajantie, E.; Kananen, L.; Hovatta, I.; Eriksson, J.G. Leukocyte telomere length and its relation to food and nutrient intake in an elderly population. Eur. J. Clin. Nutr. 2012, 66, 1290-1294. [CrossRef] [PubMed]

266. Woo, J.; Tang, N.; Leung, J. No association between physical activity and telomere length in an elderly chinese population 65 years and older. Arch. Intern. Med. 2008, 168, 2163-2164. [PubMed]

267. Mundstock, E.; Zatti, H.; Louzada, F.M.; Oliveira, S.G.; Guma, F.T.C.R.; Paris, M.M.; Rueda, A.B.; Machado, D.G.; Stein, R.T.; Jones, M.H.; et al. Effects of physical activity in telomere length: Systematic review and meta-analysis. Ageing Res. Rev. 2015, 22, 72-80. [CrossRef] [PubMed]

268. Borghini, A.; Giardini, G.; Tonacci, A.; Mastorci, F.; Mercuri, A.; Mrakic-Sposta, S.; Moretti, S.; Andreassi, M.G.; Pratali, L. Chronic and acute effects of endurance training on telomere length. Mutagenesis 2015, 30, 711-716. [CrossRef] [PubMed]

269. Latifovic, L.; Peacock, S.D.; Massey, T.E.; King, W.D. The influence of alcohol consumption, cigarette smoking, and physical activity on leukocyte telomere length. Cancer Epidemiol. Biomarkers Prev. 2016, 25, 374-380. [CrossRef] [PubMed] 
270. Saßenroth, D.; Meyer, A.; Salewsky, B.; Kroh, M.; Norman, K.; Steinhagen-Thiessen, E.; Demuth, I. Sports and exercise at different ages and leukocyte telomere length in later life-Data from the berlin aging study ii (base-ii). PLoS ONE 2015, 10, e0142131. [CrossRef] [PubMed]

271. Shadyab, A.H.; LaMonte, M.J.; Kooperberg, C.; Reiner, A.P.; Carty, C.L.; Manini, T.M.; Hou, L.; Di, C.; Macera, C.A.; Gallo, L.C.; et al. Leisure-time physical activity and leukocyte telomere length among older women. Exp. Gerontol. 2017, 95, 141-147. [CrossRef] [PubMed]

272. Soares-Miranda, L.; Imamura, F.; Siscovick, D.; Jenny, N.S.; Fitzpatrick, A.L.; Mozaffarian, D. Physical activity, physical fitness and leukocyte telomere length: The cardiovascular health study. Med. Sci. Sports Exerc. 2015, 47, 2525-2534. [CrossRef] [PubMed]

273. Mirabello, L.; Huang, W.Y.; Wong, J.Y.Y.; Chatterjee, N.; Reding, D.; Crawford, E.D.; De Vivo, I.; Hayes, R.B.; Savage, S.A. The association between leukocyte telomere length and cigarette smoking, dietary and physical variables, and risk of prostate cancer. Aging Cell 2009, 8, 405-413. [CrossRef] [PubMed]

274. Denham, J. Lack of association between pbmc telomere length and endurance exercise. J. Appl. Biomed. 2016, 15, 9-13. [CrossRef]

275. Von Kanel, R.; Bruwer, E.J.; Hamer, M.; de Ridder, J.H.; Malan, L. Association between objectively measured physical activity, chronic stress and leukocyte telomere length. J. Sports Med. Phys. Fit. 2017, 57, 1349-1358.

276. Zalli, A.; Carvalho, L.A.; Lin, J.; Hamer, M.; Erusalimsky, J.D.; Blackburn, E.H.; Steptoe, A. Shorter telomeres with high telomerase activity are associated with raised allostatic load and impoverished psychosocial resources. Proc. Natl. Acad. Sci. USA 2014, 111, 4519-4524. [PubMed]

277. Iwama, H.; Ohyashiki, K.; Ohyashiki, J.H.; Hayashi, S.; Yahata, N.; Ando, K.; Toyama, K.; Hoshika, A.; Takasaki, M.; Mori, M. Telomeric length and telomerase activity vary with age in peripheral blood cells obtained from normal individuals. Hum. Genet. 1998, 102, 397-402. [PubMed]

278. Ludlow, A.T.; Witkowski, S.; Marshall, M.R.; Wang, J.; Lima, L.C.J.; Guth, L.M.; Spangenburg, E.E.; Roth, S.M. Chronic exercise modifies age-related telomere dynamics in a tissue-specific fashion. J. Gerontol. Ser. A Biol. Sci. Med. Sci. 2012, 67, 911-926.

279. Werner, C.; Hanhoun, M.; Widmann, T.; Kazakov, A.; Semenov, A.; Poss, J.; Bauersachs, J.; Thum, T.; Pfreundschuh, M.; Muller, P. Effects of physical exercise on myocardial telomere-regulating proteins, survival pathways and apoptosis. J. Am. Coll. Cardiol. 2008, 52, 470. [PubMed]

280. Wolf, S.A.; Melnik, A.; Kempermann, G. Physical exercise increases adult neurogenesis and telomerase activity and improves behavioral deficits in a mouse model of schizophrenia. Brain Behav. Immun. 2011, 25, 971-980. [PubMed]

281. Ornish, D.; Lin, J.; Daubenmier, J.; Weidner, G.; Epel, E.; Kemp, C.; Magbanua, M.J.M.; Marlin, R.; Yglecias, L.; Carroll, P.R. Increased telomerase activity and comprehensive lifestyle changes: A pilot study. Lancet Oncol. 2008, 9, 1048-1057. [PubMed]

282. Zietzer, A.; Buschmann, E.E.; Janke, D.; Li, L.; Brix, M.; Meyborg, H.; Stawowy, P.; Jungk, C.; Buschmann, I.; Hillmeister, P. Acute physical exercise and long-term individual shear rate therapy increase telomerase activity in human peripheral blood mononuclear cells. Acta Phys. 2016, 220, 251-262.

283. Chilton, W.L.; Marques, F.Z.; West, J.; Kannourakis, G.; Berzins, S.P.; O’Brien, B.J.; Charchar, F.J. Acute exercise leads to regulation of telomere-associated genes and microrna expression in immune cells. PLOS ONE 2014, 9, e92088.

284. Britt-Compton, B.; Capper, R.; Rowson, J.; Baird, D.M. Short telomeres are preferentially elongated by telomerase in human cells. FEBS Lett. 2009, 583, 3076-3080. [PubMed]

285. Epel, E.S.; Lin, J.; Wilhelm, F.H.; Wolkowitz, O.M.; Cawthon, R.; Adler, N.E.; Dolbier, C.; Mendes, W.B.; Blackburn, E.H. Cell aging in relation to stress arousal and cardiovascular disease risk factors. Psychoneuroendocrinology 2006, 31, 277-287. [PubMed]

286. Kroenke, C.H.; Pletcher, M.J.; Lin, J.; Blackburn, E.; Adler, N.; Matthews, K.; Epel, E. Telomerase, telomere length and coronary artery calcium in black and white men in the cardia study. Atherosclerosis 2012, 220, 506-512. [PubMed]

287. Haigis, M.C.; Yankner, B.A. The aging stress response. Mol. Cell 2010, 40, 333-344. [PubMed]

288. Andersen, J.K. Oxidative stress in neurodegeneration: Cause or consequence? Nat. Med. 2004, 10, S18-S25. [PubMed]

289. Shukla, V.; Mishra, S.K.; Pant, H.C. Oxidative stress in neurodegeneration. Adv. Pharmacol. Sci. $2011,2011$. [CrossRef] 
290. Paravicini, T.M.; Touyz, R.M. Redox signaling in hypertension. Cardiovasc. Res. 2006, 71, 247-258. [PubMed]

291. Trachootham, D.; Alexandre, J.; Huang, P. Targeting cancer cells by ros-mediated mechanisms: A radical therapeutic approach? Nat. Rev. Drug Discov. 2009, 8, 579-591. [PubMed]

292. Hewitt, G.; Jurk, D.; Marques, F.; Correia-Melo, C.; Hardy, T.; Gackowska, A.; Anderson, R.; Taschuk, M.; Mann, J.; Passos, J. Telomeres are favoured targets of a persistent DNA damage response in ageing and stress-induced senescence. Nat. Commun. 2012, 3. [CrossRef]

293. Oikawa, S.; Kawanishi, S. Site-specific DNA damage at ggg sequence by oxidative stress may accelerate telomere shortening. FEBS Lett. 1999, 453, 365-368. [PubMed]

294. Von Zglinicki, T. Oxidative stress shortens telomeres. Trends Biochem. Sci. 2002, 27, 339-344. [PubMed]

295. Houben, J.M.; Moonen, H.J.; van Schooten, F.J.; Hageman, G.J. Telomere length assessment: Biomarker of chronic oxidative stress? Free Radic. Biol. Med. 2008, 44, 235-246. [PubMed]

296. Woo, J.; Suen, E.; Tang, N.L.S. Telomeres and the ageing process. Rev. Clin. Gerontol. 2010, 1-9. [CrossRef]

297. Ji, L.L.; Gomez-Cabrera, M.-C.; Vina, J. Exercise and hormesis: Activation of cellular antioxidant signaling pathway. Ann. N. Y. Acad. Sci. 2006, 1067, 425-435. [PubMed]

298. McArdle, A.; Jackson, M.J. Exercise, oxidative stress and ageing. J. Anat. 2000, 197, 539-541. [PubMed]

299. Mishra, S.; Kumar, R.; Malhotra, N.; Singh, N.; Dada, R. Mild oxidative stress is beneficial for sperm telomere length maintenance. World J. Methodol. 2016, 6, 163-170. [PubMed]

300. Radak, Z.; Chung, H.Y.; Goto, S. Exercise and hormesis: Oxidative stress-related adaptation for successful aging. Biogerontology 2005, 6, 71-75. [PubMed]

301. Urso, M.L.; Clarkson, P.M. Oxidative stress, exercise and antioxidant supplementation. Toxicology 2003, 189, 41-54. [PubMed]

302. Radák, Z.; Apor, P.; Pucsok, J.; Berkes, I.; Ogonovszky, H.; Pavlik, G.; Nakamoto, H.; Goto, S. Marathon running alters the DNA base excision repair in human skeletal muscle. Life Sci. 2003, 72, 1627-1633. [PubMed]

303. Richter, T.; von Zglinicki, T. A continuous correlation between oxidative stress and telomere shortening in fibroblasts. Exp. Gerontol. 2007, 42, 1039-1042. [PubMed]

304. Von Zglinicki, T.; Pilger, R.; Sitte, N. Accumulation of single-strand breaks is the major cause of telomere shortening in human fibroblasts. Free Radic. Biol. Med. 2000, 28, 64-74. [PubMed]

305. Büchner, N.; Zschauer, T.C.; Lukosz, M.; Altschmied, J.; Haendeler, J. Downregulation of mitochondrial telomerase reverse transcriptase induced by $\mathrm{H}_{2} \mathrm{O}_{2}$ is src kinase dependent. Exp. Gerontol. 2010, 45, 558-562. [PubMed]

306. Haendeler, J.; Dröse, S.; Büchner, N.; Jakob, S.; Altschmied, J.; Goy, C.; Spyridopoulos, I.; Zeiher, A.M.; Brandt, U.; Dimmeler, S. Mitochondrial telomerase reverse transcriptase binds to and protects mitochondrial DNA and function from damage. Arterioscler. Thromb. Vasc. Biol. 2009, 29, 929-935. [PubMed]

307. Khan, S.; Chuturgoon, A.A.; Naidoo, D.P. Telomeres and atherosclerosis: Review article. Cardiovasc. J. Afr. 2012, 23, 563-571. [PubMed]

308. O'Donovan, A.; Pantell, M.S.; Puterman, E.; Dhabhar, F.S.; Blackburn, E.H.; Yaffe, K.; Cawthon, R.M.; Opresko, P.L.; Hsueh, W.-C.; Satterfield, S.; et al. Cumulative inflammatory load is associated with short leukocyte telomere length in the health, aging and body composition study. PLoS ONE 2011, 6, e19687.

309. Akiyama, M.; Yamada, O.; Hideshima, T.; Yanagisawa, T.; Yokoi, K.; Fujisawa, K.; Eto, Y.; Yamada, H.; Anderson, K.C. TNFA induces rapid activation and nuclear translocation of telomerase in human lymphocytes. Biochem. Biophys. Res. Commun. 2004, 316, 528-532. [PubMed]

310. Aviv, A. Telomeres and human aging: Facts and fibs. Sci. Aging Knowl. Environ. 2004, 2004, pe43.

311. Jaiswal, M.; LaRusso, N.F.; Burgart, L.J.; Gores, G.J. Inflammatory cytokines induce DNA damage and inhibit DNA repair in cholangiocarcinoma cells by a nitric oxide-dependent mechanism. Cancer Res. 2000, 60, 184-190. [PubMed]

312. Parish, S.T.; Wu, J.E.; Effros, R.B. Modulation of $\mathrm{t}$ lymphocyte replicative senescence via TNF- $\alpha$ inhibition: Role of caspase-3. J. Immunol. 2009, 182, 4237-4243. [PubMed]

313. Xu, D.; Erickson, M.; Szeps, A.; Gruber, O.; Sangfelt, S.; Einhorn, P.P.; Grander, D. Interferon alpha downregulates telomerase reverse transcriptase and telomerase activity in human malignant and nonmalignant hematopoietic cells. Blood 2000, 96, 4313-4318. [PubMed] 
314. Coppé, J.-P.; Patil, C.; Rodier, F.; Sun, Y.; Muñoz, D.; Goldstein, J.; Nelson, P.; Desprez, P.-Y.; Campisi, J. Senescence-associated secretory phenotypes reveal cell-nonautonomous functions of oncogenic RAS and the p53 tumor suppressor. PLoS Biol. 2008, 6, e301.

315. Rodier, F.; Coppe, J.P.; Patil, C.K.; Hoeijmakers, W.A.; Munoz, D.P.; Raza, S.R.; Freund, A.; Campeau, E.; Davalos, A.R.; Campisi, J. Persistent DNA damage signalling triggers senescence-associated inflammatory cytokine secretion. Nat. Cell Biol. 2009, 11, 1272. [CrossRef]

316. Beavers, K.M.; Brinkley, T.E.; Nicklas, B.J. Effect of exercise training on chronic inflammation. Clin. Chim. Acta 2010, 411, 785-793. [PubMed]

317. Woods, J.A.; Vieira, V.J.; Keylock, K.T. Exercise, inflammation and innate immunity. Immunol. Allergy Clin. N. Am. 2009, 29, 381-393.

318. Kendig, E.L.; Le, H.H.; Belcher, S.M. Defining hormesis: Evaluation of a complex concentration response phenomenon. Int. J. Toxicol. 2010, 29, 235-246. [PubMed]

319. Radak, Z.; Chung, H.Y.; Koltai, E.; Taylor, A.W.; Goto, S. Exercise, oxidative stress and hormesis. Hormesis 2008, 7, 34-42.

320. Ludlow, A.T.; Lima, L.C.; Wang, J.; Hanson, E.D.; Guth, L.M.; Spangenburg, E.E.; Roth, S.M. Exercise alters mrna expression of telomere-repeat binding factor 1 in skeletal muscle via p38 MAPK. J. Appl. Physiol. 2012, 113, 1737-1746. [PubMed]

321. Fraga, M.F.; Ballestar, E.; Villar-Garea, A.; Boix-Chornet, M.; Espada, J.; Schotta, G.; Bonaldi, T.; Haydon, C.; Ropero, S.; Petrie, K.; et al. Loss of acetylation at Lys16 and trimethylation at Lys20 of histone H4 is a common hallmark of human cancer. Nat. Genet. 2005, 37, 391-400. [PubMed]

322. Tommerup, H.; Dousmanis, A.; de Lange, T. Unusual chromatin in human telomeres. Mol. Cell. Biol. 1994, 14, 5777-5785. [PubMed]

323. Van Overveld, P.G.M.; Lemmers, R.J.F.L.; Sandkuijl, L.A.; Enthoven, L.; Winokur, S.T.; Bakels, F.; Padberg, G.W.; van Ommen, G.-J.B.; Frants, R.R.; van der Maarel, S.M. Hypomethylation of D4Z4 in 4q-linked and non-4q-linked facioscapulohumeral muscular dystrophy. Nat. Genet. 2003, 35, 315-317. [PubMed]

324. Blasco, M.A. The epigenetic regulation of mammalian telomeres. Nat. Rev. Genet. 2007, 8, 299-309. [PubMed]

325. García-Cao, M.; O'Sullivan, R.; Peters, A.H.; Jenuwein, T.; Blasco, M.A. Epigenetic regulation of telomere length in mammalian cells by the Suv39h1 and Suv39h2 histone methyltransferases. Nat. Genet. 2003, 36, 94-99. [PubMed]

326. Peuscher, M.H.; Jacobs, J.J.L. Posttranslational control of telomere maintenance and the telomere damage response. Cell Cycle 2012, 11, 1524-1534. [PubMed]

327. Walker, J.R.; Zhu, X.-D. Post-translational modifications of TRF1 and TRF2 and their roles in telomere maintenance. Mech. Ageing Dev. 2012, 133, 421-434. [PubMed]

328. Dinami, R.; Ercolani, C.; Petti, E.; Piazza, S.; Ciani, Y.; Sestito, R.; Sacconi, A.; Biagioni, F.; le Sage, C.; Agami, R.; et al. Mir-155 drives telomere fragility in human breast cancer by targeting TRF1. Cancer Res. 2014, 74, 4145-4156. [PubMed]

329. Lytle, J.R.; Yario, T.A.; Steitz, J.A. Target mrnas are repressed as efficiently by microrna-binding sites in the $5^{\prime}$ UTR as in the 3' UTR. Proc. Natl. Acad. Sci. USA 2007, 104, 9667-9672. [PubMed]

330. Chan, S.Y.; Zhang, Y.Y.; Hemann, C.; Mahoney, C.E.; Zweier, J.L.; Loscalzo, J. Microrna-210 controls mitochondrial metabolism during hypoxia by repressing the iron-sulfur cluster assembly proteins ISCU1/2. Cell Metab. 2009, 10, 273-284. [PubMed]

331. Davidson-Moncada, J.; Papavasiliou, F.N.; Tam, W. Micrornas of the immune system. Ann. N. Y. Acad. Sci. 2010, 1183, 183-194. [PubMed]

332. Davidsen, P.K.; Gallagher, I.J.; Hartman, J.W.; Tarnopolsky, M.A.; Dela, F.; Helge, J.W.; Timmons, J.A.; Phillips, S.M. High responders to resistance exercise training demonstrate differential regulation of skeletal muscle microrna expression. J. Appl. Physiol. 2011, 110, 309-317. [PubMed]

333. Williams, A.H.; Liu, N.; van Rooij, E.; Olson, E.N. Microrna control of muscle development and disease. Curr. Opin. Cell Biol. 2009, 21, 461-469. [PubMed]

334. Zhang, C. Micrornas in vascular biology and vascular disease. J. Cardiovasc. Transl. Res. 2010, 3, $235-240$. [PubMed]

335. Radom-Aizik, S.; Zaldivar, F.; Oliver, S.; Galassetti, P.; Cooper, D.M. Evidence for microRNA involvement in exercise-associated neutrophil gene expression changes. J. Appl. Physiol. 2010, 109, 252-261. [PubMed] 
336. Radom-Aizik, S.; Zaldivar, F., Jr.; Leu, S.Y.; Adams, G.R.; Oliver, S.; Cooper, D.M. Effects of exercise on microRNA expression in young males peripheral blood mononuclear cells. Clin. Transl. Sci. 2012, 5, 32-38. [PubMed]

337. Radom-Aizik, S.; Zaldivar, F.; Haddad, F.; Cooper, D.M. Impact of brief exercise on peripheral blood NK cell gene and microRNA expression in young adults. J. Appl. Physiol. 2013, 114, 628-636. [PubMed]

338. Radom-Aizik, S.; Zaldivar, F.P., Jr.; Haddad, F.; Cooper, D.M. Impact of brief exercise on circulating monocyte gene and microRNA expression: Implications for atherosclerotic vascular disease. Brain Behav. Immun. 2014, 39, 121-129. [PubMed]

339. Tonevitsky, A.G.; Maltseva, D.V.; Abbasi, A.; Samatov, T.R.; Sakharov, D.A.; Shkurnikov, M.U.; Lebedev, A.E.; Galatenko, V.V.; Grigoriev, A.I.; Northoff, H. Dynamically regulated mirna-mrna networks revealed by exercise. BMC Physiol. 2013, 13. [CrossRef]

340. Neves, V.J.; Fernandes, T.; Roque, F.R.; Soci, U.P.R.; Melo, S.F.S.; de Oliveira, E.M. Exercise training in hypertension: Role of microRNAs. World J. Cardiol. 2014, 6, 713-727. [PubMed]

341. Kasiappan, R.; Shen, Z.; Tse, A.K.-W.; Jinwal, U.; Tang, J.; Lungchukiet, P.; Sun, Y.; Kruk, P.; Nicosia, S.V.; Zhang, X.; et al. 1,25-dihydroxyvitamin D3 suppresses telomerase expression and human cancer growth through microRNA-498. J. Biol. Chem. 2012, 287, 41297-41309. [PubMed]

342. Castro-Vega, L.J.; Jouravleva, K.; Liu, W.-Y.; Martinez, C.; Gestraud, P.; Hupé, P.; Servant, N.; Albaud, B.; Gentien, D.; Gad, S.; et al. Telomere crisis in kidney epithelial cells promotes the acquisition of a microRNA signature retrieved in aggressive renal cell carcinomas. Carcinogenesis 2013, 34, 1173-1180. [PubMed]

343. Buxton, J.L.; Suderman, M.; Pappas, J.J.; Borghol, N.; McArdle, W.; Blakemore, A.I.F.; Hertzman, C.; Power, C.; Szyf, M.; Pembrey, M. Human leukocyte telomere length is associated with DNA methylation levels in multiple subtelomeric and imprinted loci. Sci. Rep. 2014, 4, 4954. [PubMed]

344. Wong, J.Y.Y.; De Vivo, I.; Lin, X.; Grashow, R.; Cavallari, J.; Christiani, D.C. The association between global DNA methylation and telomere length in a longitudinal study of boilermakers. Genet. Epidemiol. 2014, 38, 254-264. [PubMed]

345. Gonzalo, S.; Jaco, I.; Fraga, M.F.; Chen, T.; Li, E.; Esteller, M.; Blasco, M.A. DNA methyltransferases control telomere length and telomere recombination in mammalian cells. Nat. Cell Biol. 2006, 8, 416-424. [PubMed]

346. Ng, L.J.; Cropley, J.E.; Pickett, H.A.; Reddel, R.R.; Suter, C.M. Telomerase activity is associated with an increase in DNA methylation at the proximal subtelomere and a reduction in telomeric transcription. Nucleic Acids Res. 2009, 37, 1152-1159. [PubMed]

347. Azzalin, C.M.; Reichenbach, P.; Khoriauli, L.; Giulotto, E.; Lingner, J. Telomeric repeat-containing rna and rna surveillance factors at mammalian chromosome ends. Science 2007, 318, 798-801. [PubMed]

348. Schoeftner, S.; Blasco, M.A. Developmentally regulated transcription of mammalian telomeres by DNA-dependent RNA polymerase II. Nat. Cell Biol. 2008, 10, 228-236. [PubMed]

349. Deng, Z.; Norseen, J.; Wiedmer, A.; Riethman, H.; Lieberman, P.M. Terra rna binding to TRF2 facilitates heterochromatin formation and orc recruitment at telomeres. Mol. Cell 2009, 35, 403-413. [PubMed]

350. Arora, R.; Lee, Y.; Wischnewski, H.; Brun, C.M.; Schwarz, T.; Azzalin, C.M. RNaseH1 regulates TERRA-telomeric DNA hybrids and telomere maintenance in ALT tumour cells. Nat. Commun. 2014, 5, 5220. [PubMed]

351. Balk, B.; Maicher, A.; Dees, M.; Klermund, J.; Luke-Glaser, S.; Bender, K.; Luke, B. Telomeric RNA-DNA hybrids affect telomere-length dynamics and senescence. Nat. Struct. Mol. Biol. 2013, 20, 1199-1205. [PubMed]

352. Pfeiffer, V.; Crittin, J.; Grolimund, L.; Lingner, J. The tho complex component THP2 counteracts telomeric R-loops and telomere shortening. EMBO J. 2013, 32, 2861-2871. [PubMed]

353. Yu, T.-Y.; Kao, Y.-W.; Lin, J.-J. Telomeric transcripts stimulate telomere recombination to suppress senescence in cells lacking telomerase. Proc. Natl. Acad. Sci. USA 2014, 111, 3377-3382. [PubMed]

354. Ginno, P.A.; Lott, P.L.; Christensen, H.C.; Korf, I.; Chédin, F. R-loop formation is a distinctive characteristic of unmethylated human cpg island promoters. Mol. Cell 2012, 45, 814-825.

355. Skourti-Stathaki, K.; Proudfoot, N.J.; Gromak, N. Human senataxin resolves RNA/DNA hybrids formed at transcriptional pause sites to promote Xrn2-dependent termination. Mol. Cell 2011, 42, 794-805. [PubMed]

356. Arnoult, N.; Van Beneden, A.; Decottignies, A. Telomere length regulates terra levels through increased trimethylation of telomeric H3K9 and HP1A. Nat. Struct. Mol. Biol. 2012, 19, 948-956. [CrossRef] [PubMed] 
357. Cusanelli, E.; Romero, C.A.; Chartrand, P. Telomeric noncoding RNA terra is induced by telomere shortening to nucleate telomerase molecules at short telomeres. Mol. Cell 2013, 51, 780-791. [PubMed]

358. Porro, A.; Feuerhahn, S.; Delafontaine, J.; Riethman, H.; Rougemont, J.; Lingner, J. Functional characterization of the terra transcriptome at damaged telomeres. Nat. Commun. 2014, 5, 5379. [PubMed]

359. Hansen, M.E.B.; Hunt, S.C.; Stone, R.C.; Horvath, K.; Herbig, U.; Ranciaro, A.; Hirbo, J.; Beggs, W.; Reiner, A.P.; Wilson, J.G.; et al. Shorter telomere length in europeans than in africans due to polygenetic adaptation. Hum. Mol. Genet. 2016, 25, 2324-2330. [CrossRef] [PubMed]

360. Mangino, M.; Christiansen, L.; Stone, R.; Hunt, S.C.; Horvath, K.; Eisenberg, D.T.A.; Kimura, M.; Petersen, I.; Kark, J.D.; Herbig, U.; et al. DCAF4, a novel gene associated with leucocyte telomere length. J. Med. Genet. 2015, 52, 157-162. [CrossRef] [PubMed]

361. Stone, R.C.; Horvath, K.; Kark, J.D.; Susser, E.; Tishkoff, S.A.; Aviv, A. Telomere length and the cancer-atherosclerosis trade-off. PLoS Genet. 2016, 12, e1006144.

362. Berardinelli, F.; Nieri, D.; Sgura, A.; Tanzarella, C.; Antoccia, A. Telomere loss, not average telomere length, confers radiosensitivity to TK6-irradiated cells. Mutat. Res. 2012, 740, 13-20. [PubMed]

363. Vera, E.; Bernardes de Jesus, B.; Foronda, M.; Flores, J.M.; Blasco, M.A. The rate of increase of short telomeres predicts longevity in mammals. Cell Rep. 2012, 2, 732-737. [PubMed]

364. Zhan, Y.; Karlsson, I.K.; Karlsson, R.; Tillander, A.; Reynolds, C.A.; Pedersen, N.L.; Hägg, S. Exploring the causal pathway from telomere length to coronary heart disease: A network mendelian randomization study. Circ. Res. 2017, 121, 214-219. [PubMed]

(C) 2017 by the authors. Licensee MDPI, Basel, Switzerland. This article is an open access article distributed under the terms and conditions of the Creative Commons Attribution (CC BY) license (http://creativecommons.org/licenses/by/4.0/). 